Historic, Archive Document

Do not assume content reflects current scientific knowledge, policies, or practices. 



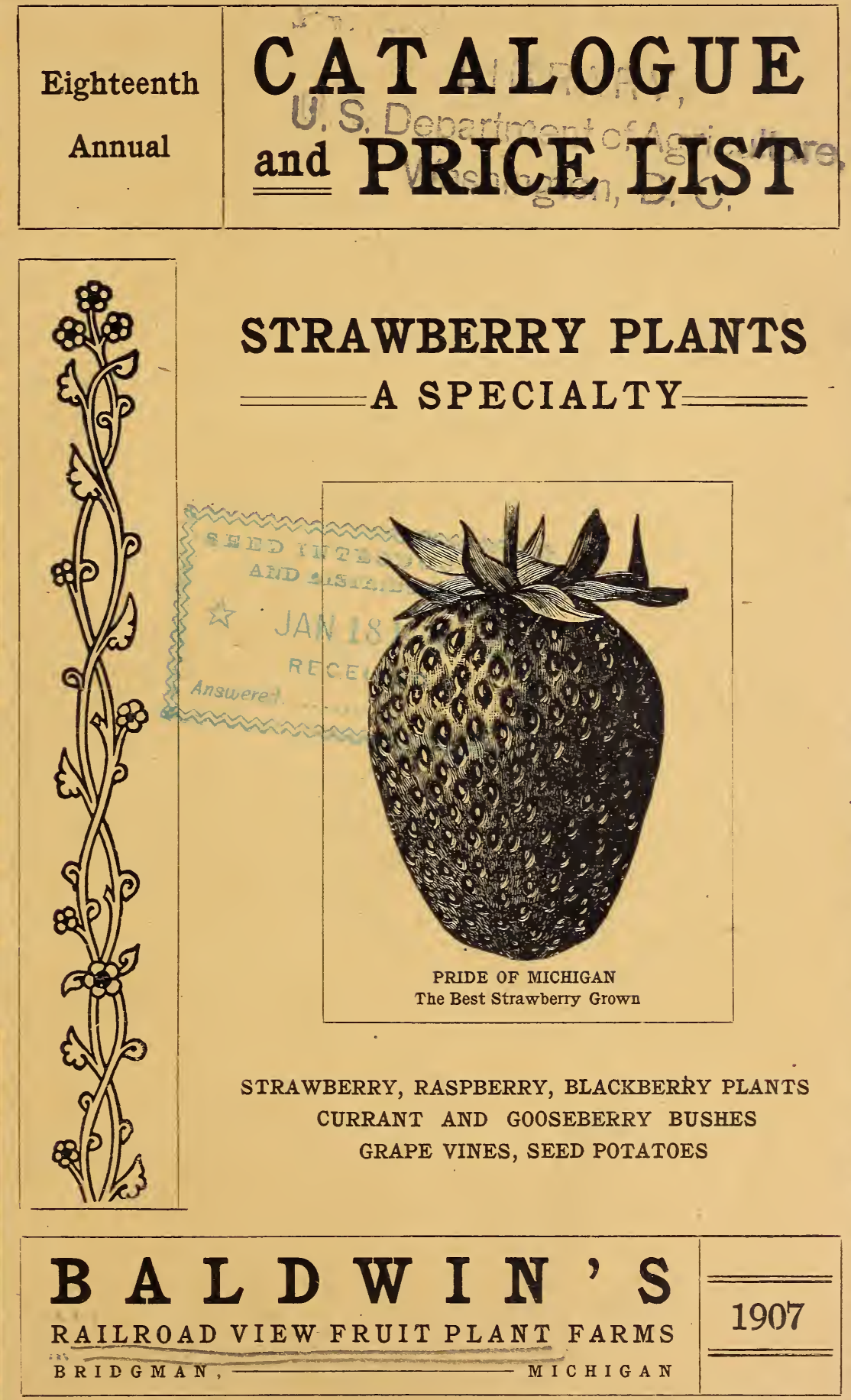



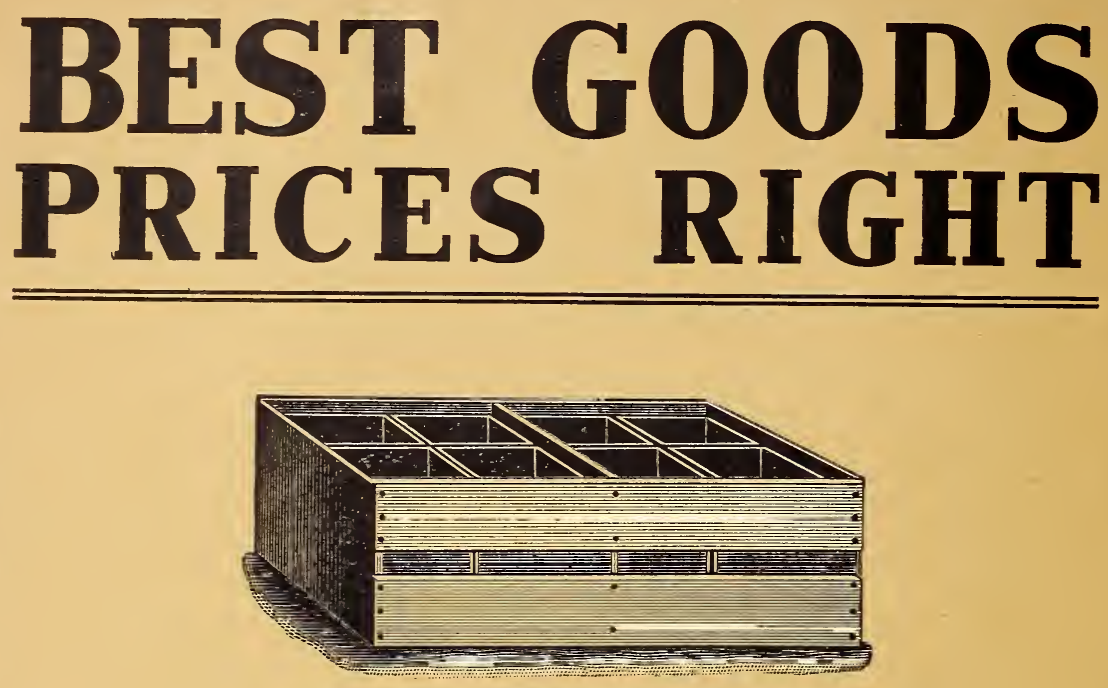

BERRY CRATES BERRY BOXES

Goods sent in Flat or Made Up.

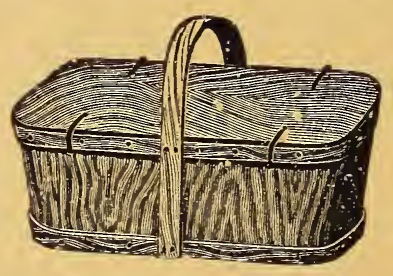

BASKETS FHIPPING
GRAPES and PEACHES

ALL KINDS OF FRUIT AND VEGETABLE PACKAGES

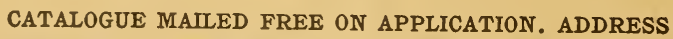 \\ COLBY-HINKLEY CO., Benton Harbor, Michigan.}




\section{BALDWIN'S FRUIT PLANT CATALOG 1907}

For eighteen consecutive years we have issued a fruit plant catalogue. In preparing copy for this one we wish first to again thank our many customers and friends throughout the country for their continued patronage and assistance, and to assure them of our most careful attention and treatment in the future. With your co-operation our business has increased until we now operate one of the very largest small fruit nurseries in the United States.

This catalogue will go to thirty thousand families living on farms throughout the Unted States and Southern Canada. It is our only salesman.

Our whole business depends almost entirely upon the descriptions of our stock and prices quoted on same in this little book.

Consequently it will be our aim and to our advantage to describe everything carefully and honestly as we find it, and to make our prices right.

We continue to receive orders from our former customers year after year, and we believe that this fact alone is as good advertising as we can get. It certainly proves that our plants and seed potatoes give satisfaction.

Many nurserymen catalogue more varieties than we do, but we have a good list of all the varieties that have proved themselves worthy of praise on our grounds. We have fruited nearly everything we catalogue and are in a position to describe each variety thoroughly.

We are listing but one new strawberry this year, I believe, and that one is Pride of Michigan (the variety we introduced in 1906).

This variety is not an untried, fake affair to catch easy money, as we have watched it carefully for five consecutive years and we know that Pride of Michigan is by far the most profitable strawberry grown on our farms.

We have thrown out several nearly worthless varieties, hence our list is somewhat smaller than last year.

None of our plants are allowed to fruit before digging, and when we dig we take up the whole row, thereby giving our customers the strongest stock that can be grown. All plants are carefully trimmed and tied in bunches of twentyfive. Small plants are thrown out. Everything we ship will be as represented.

Ten hundred good strong plants in every thousand, packed to reach you in good condition and give satisfaction:

W'e invite all our customers who can to come and examine our growing plants. While our present acreage is not quite so large as last year, our stock of plants is heavier.

We do not think our fields of strawberry plants ever went into the winter in better condition than they did this fall.

Our cane and tip plants are also extra heavy rooted this year, owing to our having had plenty of rainfall and an extra fine growing season all through.

We publish in this catalogue a few of the many unsolicited testimonials received during the past year.

we have pleased these people and we believe we can please you. In fact, we are dead sure we can, if given a fair chance. Are you already a customer of 
ours? If not, why not give us a trial order this year? Even if your order is small, it will receive just as careful attention, and this will give us an opportunity to get acquainted, and if our acquaintance proves a mutual "good thing," we can probably have more business together in 1908.

A few reasons we have for believing we can please you with our plants and save you some money:

We have plenty of rich, well drained land especially adapted for growing strong, healthy plants.

We have our own moss for packing and can use enough to keep plants in good condition for some time at very small cost to us. (This means something to you.)

We have a full force of experienced help-men and women who have been with us from flve to twelve years and who have learned to pack plant to our satisfaction and to the satisfaction of our thousands of customers throughout the United States and Canada.

Of course our folks make mistakes sometimes, and when they do and it is called to our attention, we make good to our customers.

\section{Scarcity of Plants for 1907.}

We find there is a marked scarcity of strawberry and black raspberry plants all through the country this year. We believe the demand for 1907 planting will greatly exceed the supply. We have catalogued all varieties at about the same price, as in 1906. and fully expect to sell out of everything by April 1st.

Wo earnestly advise all to place their orders just as soon as possible, and especially urge our former customers and friends to order early that they may not be disappointed as we have been obliged to disappoint them sometimes in past years.

Iet us hear from you soon, and do not be afrald to ask questlons. Your letters will receive prompt and careful attention. Please remember that jou are always welcome to any information we are able to glve you.

\section{Our Location.}

We are located in Berrien County, the greatest strawberry county in the state, where plant growth is as perfect as anywhere in the United States.

Plants grown in the cold, northern climate are strong and hardy, and when transplanted will grow and bear fruit. We are one and one-half miles from Lake Michigan on the Pere Marquette R. R., thirteen miles from the great trunk lines like Michigan Central, I., I. \& I., and Big Four, making quick connections to all sections of the United States.

Our stock is fine. Everything we ship is strictly first class, guaranteed to be true to name. We will book your order for one-half dozen or 500,000 plants and guarantee to please you in every particular. We raise plants by the million on our own ground under our personal supervision, and we know what we are selling. If we did not we could not guarantee that everything would be as represented. Our trade extends to all sections of the United States and Canada and is increasing steadily. Our prices average about the same as last year. We beHeve our prices will compare favorably with any reliable nursery. We do not wish to try to compete with other than respunsible parties.

VARIETIES.-Our strawberry list contains about forty of the best varieties there are. Every year we sell out of some varieties and are then obliged to return money sent or substitute other varieties (if permitted to do so). This year we have thrown out several varieties that seem to be worthless, and are cataloging only those which have proven themselves to be profitable fruit producers.

We have added but one or two varieties.

Pride of Michigan is by far the best of all late introductions, and we want to add only those that are profitable and will please our customers.

BOXING AND PACKING.-We make no charge for boxes, barrels and packing, which is done in best possible manner. We use thousands of light plant crates and handled baskets for express, and heavier ones for freight. We manu- 
facture our own crates for shipping. We pack in moss and straw, of which we use many tons each year. It is very seldom that any of our customers report arrival of plants in poor condition on account of not being properly packed.

METHODS OF SHIPMFNT.-BY MAII.-The reduction in postage on plants enables us to send small amounts to distant sections at small cost and thus place in customer's hands a few of a kind cheaper than they could procure them of their nearest nursery.

BY EXPRESS.-This is the safest and, all things considered, the cheapest way of shipping strawberry plants. It is the method most commonly used for carrying large bills to distant parts of the country, as there is no delay as sometimes occurs by freight. Plants go for 20 per cellt. less by express than other goods. Some nurserymen will tell you that they have secured a cut rate; this is not the case, all receive the same rate.

We advise all to order their strawberry plants shipped by express. We guarantee safe arrival of all stock shipped by mail or express.

BY FRIGIF.-We ship large amounts of stock long distances by fast freight. Nearly all the plants bought of us by nurseries and dealers all over the United States to sell again are ordered sent by freight. All such should be ordered early. Many ask, "How far can you ship by freight?" We have shipped safely as far west as the Pacific and east as the Atlantic. We send large bills by freight every year into all parts of the United States and Canada, and most go through safely, but of course delays sometimes occur and stock is injured. As the buyer is the one benefited by freight rates, he must take the risk. Cane plants of all kinds generally go through safely by freight, if distance is not too great.

\section{Time to Order.}

ORDER EARIY by all means-the earlier the better. If any thing more is needed it can be added later; - besides we give liberal discounts on early orders. If not prepared to send all the money, send a part when the order will be booked; the balance before shipment.

Orders are filled in rotation as received, hence it is to your advantage to have your order booked early. At this writing (Nov. 1st) we have several orders on our books for spring shipment.

substitution.-We do not substitute one variety for another without your permission.

It is sometimes a great help to us and also a good thing for our customers if we are allowed to substitute for some variety we may happen to be sold out of. We always substitute some variety of same season, sex and quality as that ordered, and generally give customers no cause for complaint. Should you give us the permission, we will not substitute, of course, unless it is absolutely necessary.

Our Terms are Cash.-No order is booked unless accompanied by a remittance as a guarantee of good faith; the balance before shipment. At our prices we cannot afford to do a credit business. We give.references as to our reliability, etc., which all are at liberty to investigate. Our prices are low for cash. As we have said heretofore, we have been "beat" so many times by dishonest men that we must refuse all orders unless money is sent.

Iiability.-While we take the greatest pains to have our stock pure and unmixed and true to name, mistakes will sometimes occur, and if found to be our fault, we will either replace stock not found to be true or refund the money.

Remember, we are never liable for more than first cost of plants.

References, as to our standing and reliability we refer, by permission to the Postmaster or Express Agent of Bridgman; County Treasurer, St. Joseph, Mich., and Commercial National Bank, of St. Joseph, Mich. In writing to above, please enclose stamp for reply.

How to Send Money.-By Chicago or New York draft, express money order, postoffice money order, or registered letter. 


\section{Season for Shipping.}

We commence to ship the last of March or first of April, according to season, and continue till all stock is gone (generally about May 20 th to 25 th).

We have sufficient help to pack out 500,000 strawberry and 100,000 cane plants every day during our entire shipping season. This means prompt service for you. We issue no fall catalogue, but send out some stock after October 1st. Plants in this latitude do not mature before this date and would not give satisfaction. They are full grown and heavy rooted by October 1st, and as some had rather plant in fall, we will ship what orders we receive then at prices quoted in this catalogue. Please do not ask us to ship plants until October.

If more than one catalogue should be received, please hand to some neighbor and oblige. Also, if you have neighbors (fruit growers) that you think would like our catalogue, if you will send a few names on a postal card we will mail them one, and will send you a few plants for your trouble.

\section{Estimates.}

If you want a quantity of plants write us at once for special discount. We can of course sell cheaper accordingly when filling a large order than a small one. Bills for low quotations must be received early, when stock is unbroken.

\section{Note Prices on Grape Vines.}

We want to call your special attention to our low prices on all varieties of grape vines. We have an extra large stock of the leading grapes, and they are fine, heavy rooted, healthy vines, carefully graded, and we guarantee entire satisfaction to every purchaser. May we have your order for grape vines?

\section{Scarcity of Seed Potatoes.}

You all know what a short crop of potatoes there was throughout the country this year.

Our stock is not large and of course will be sold early at prices quoted in this catalogue. We advise all our friends and former customers to place their orders for seed potatoes just as soon as possible, so that we may hold them for you.

Our stock is in fine shape in cellars and will be kept at even temperature till shipping season. All strictly first class seed, absolutely pure, and guaranteed to please you.

\section{A Few Pointers.}

The following table may assist some in determining how many plants they will need for a certain piece of ground.

\section{NUMBEE OF PIANTS REQUTRED TO SET ONE ACRE.}

\begin{tabular}{|c|c|c|}
\hline \multicolumn{3}{|c|}{ Distance. } \\
\hline by & foot. & $\ldots \ldots \ldots \ldots \ldots \ldots \ldots \ldots, 560$ \\
\hline by & 1 foot. & \\
\hline by 2 & feet. & $\ldots \ldots \ldots \ldots \ldots \ldots \ldots$ \\
\hline by 1 & foot. & $\ldots \ldots \ldots \ldots \ldots \ldots \ldots \ldots \ldots$ \\
\hline by 2 & feet. & $\ldots \ldots \ldots \ldots \ldots \ldots$ \\
\hline by 3 & feet. & $\ldots \ldots \ldots \ldots \ldots \ldots \ldots$ \\
\hline by & foot. & $\ldots \ldots \ldots \ldots \ldots \ldots$ \\
\hline by & feet. & $\ldots \ldots \ldots \ldots \ldots \ldots$ \\
\hline by & feet. & $\ldots \ldots \ldots \ldots \ldots \ldots \ldots$ \\
\hline by & feet. & $\ldots \ldots \ldots \ldots \ldots \ldots$ \\
\hline & I00t. & $\ldots \ldots \ldots \ldots \ldots \ldots \ldots$ \\
\hline & reet. & $\ldots \ldots \ldots \ldots \ldots \ldots \ldots$ \\
\hline & leet. & $\cdots \ldots \ldots \ldots \ldots \ldots$ \\
\hline & & $\cdots \ldots \ldots \ldots \ldots \ldots$ \\
\hline by & & $\ldots \ldots \ldots \ldots$ \\
\hline & & $\because$ \\
\hline
\end{tabular}

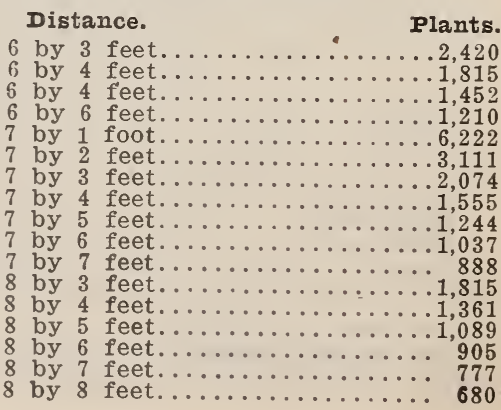


We set strawbe:ry plants 16 to 18 inches apart in row and rows 4 feet apart. This takes about 7,000 per acre. For fruiting row we would recommend about 6,000 per acre. We set raspberry plants 4 by 6 feet. If wanted to cultivate both ways they can be set 5 by 5 feet. Blackberry plants can be set 4 by 6 feet, or 4 by 7 feet, or if you want to cultivate both ways, set 6 by 6 feet.

In figuring express rates remember that from three to four thousand strawberry plants weigh 100 Ibs. (boxed and packed).

Soil for strawberries.-Almost any soil that will grow good field crops will grow good strawberries-good, rich, well arained sandy loam preferred.

Plant every fourth row to some staminate variety. Let them make a matted row. Newly cleared land is good for strawberries. We make a practice of clearing up several acres of new land and setting to strawberries every year, and while the labor of attending is more than on old, run-out land the plants produced are the best and most healthy grown.

Drainage--See that your land is well drained. Tiling of sufficient size to carry off all surplus water is best and saves ground for you.

\section{Preparing Ground.}

Ground for setting fruit plants should be plowed deep and harrowed till all lumps are smashed and it is loose and level. Then roll or float.just before setting We use common plank float which you can make at very little expense. We use a hand marker (home made) that marks three rows at once.

Setting Plants.-Make holes with a spade by putting in ground five or six inches and puil toward you, then take out. Hold plant in hole with hand and close hole wirh foot and press firmly (with feet) on both sides.

This is for strawberry plants. For raspberry and blackberry plants we generally plow furrow with one-horse plow and fill in around plant with hook or hoe and press soil around plant firmly with feet.

\section{Fertilizing.}

The best fertilizer we ever found for fruit is stable manure. A crop of clover or other green crop plowed under is good. too. Fruit plants, like any other crop, need rich ground, and respond quickly to good care and fertilization.

If you have a good market, you can make more clear money raising fruit than by any o+her branch of farming. Iet us start you in, in a small way, and prove the above statement.

\section{Read Carefully.}

When writing, please sign your name plainly. Be sure to give your postoffice, county and state. Every year we receive letters with postoffice and state left off-many times no signature. Use order sheet and return envelope, fill out carefully, änd much delay and trouble will be avoided.

\section{Our Advertisers.}

We carry a few advertisements of articles that will interest you. Ail these people we believe to be absolutely honest and reliable and we recommend their goods to our customers with the assurance that, should you patronize these people, you will get good goods and careful treatment. We have dealt with most of these parties for jears.

Colby-Hinkley Co. are well known and reliable fruit package manufacturers.

As this catalogue will go to over two thousand fruit growers in Berrien county we want to call your attention to the ad. of the Commercial National Bank. The officials and employees are gentlemen with whom it is a pleasure to deal. Try them. They will use you right. 
We use and recommend Rhodes pruning shears.

The seeders advertized by The Cyclone Seeder Co., of Urbana, Ind., are used on our farm. They are perfect.

\section{Please Note Our Premium Offers.}

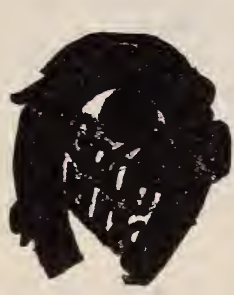

.

For an order of $\$ 10.00$ or more at catalog price, received early (before March 1st), customers will be allowed to select stock to the amount of $\$ 1.00$ free, if this offer is mentioned; that is, you may select stock to the amount of $\$ 11.00$ and send us $\$ 10.00$ as full payment for same.

For an order of $\$ 5.00$, at catalog price, we will give the Biggle Berry Book, by Judge Biggle, or any of the other Biggle books, viz.: "Biggle Horse Book," "Biggle Poultry Book," "Biggle Cow Book," Biggle Swine Book," Biggle Health Book," "Biggle Pet Book," and "Biggle Sheep Book.". The boolss are models of the printer's art, beautifully illustrated, cloth bound, boiled down, common sense, cream, not skim milk. Beautiful color illustrations in the berry, 'cow and poultry books.

These "Biggle Books" are the most valuable books for their size that we have ever read. They answer every question that one could ask in their line and tell it so plainly that all can understand it, but at the same time very breifly. We sell them at $50 \mathrm{c}$ each, postpaid, to any address.

For orders of $\$ 3.00$ or over at catalog price (if noted at bottom of order sheet) by special arrangement we áre able to give you one year's subscription to "The National Fruit Grower" published at St. Joseph, Mich. This is one of the very best fruit publications in this country. (Regular subscription price, 50c.) If you are already a subscriber, your subscription will be extended one year from the date it now expires.

The Strawbery is our specialty. We have a fine stock of all the standard and best new varieties, which we have listed very low and shall sell at prices quoted as long as stock lasts. Almost all the newer varieties we obtained from the originators and introducers in the first place at a heavy expense, consequently our stock is pure. Many ask how we can sell such choice stock so low. Being situated in a section especially adapted to growing the finest plants and not being hampered with anything in the tree line, growing many of the standards by the hundred thousand on new, rich land that produces a heavy stock of extra fine plants, having our own moss for packing and being satisfied with a small profit, we can furnish choice stock very low. Growing plants in such large quantities we can, of course, make a discount on large bills. Thus nurseries in all sections of the country buy of us to sell again-many times selling through agents as high by the hundred as we charge by the thousand. Our low prices hold good while stock lasts. We have some varieties not listed here; if you want something not on this list, write us.

Many new beginners ask what varieties are most profitable to grow for market, etc. Of course, much depends on location and circumstances. The general favorites are the following:

Bubach, Warfield, Senator Dunlap, Haverland, Beder Wood, Iovett, Glenn Mary, Crescent, Aroma, Sample, August Iuther and Pocomoke. These varieties range from very early to very late.

We recommend August Iuther for early; Aroma, Sample and Brandywine for late.

Senator Dunlap is rapidly coming to the front as a money maker and we think it is now one of our most profitable market berries.

We recommend Pride of Michigan above all others. This is sure to be the leading market and home-use strawberry in this country. Our neighbors here are planting it extensively for Chicago market. 


\section{Fumigation.}

All cane plants shipped, if requested, are fumigated with Hydro Cyanic Acid Gas of strength required by law. This process kills all insects, etc., that is raising such havoc with cane fruit, trees, etc.; also kills San Jose scale germ.

No. 710.

This is to certify that I have examined the Nursery Stock of $\mathbf{O}$. A. $\mathbf{E}$. BAIDWIN, Bridgman, Michigan, and find it apparently free from dangerous insects and dangerously contagious tree and plant diseases.

This certificate to be void after July $31,1907$.

I. R. TAFT,

State Inspector of Nurseries and Orchards.

Agricultural College, Michigan, October 18, 1906.

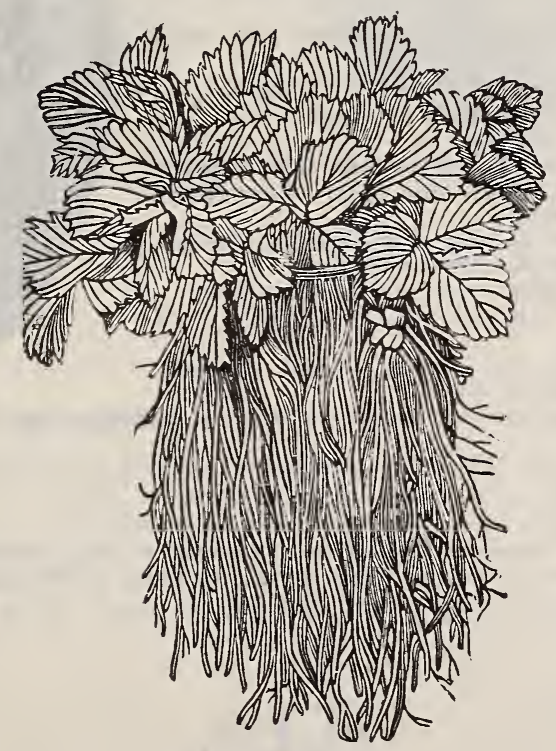




\title{
Varieties of Strawberries
}

\author{
For price by the dozen or hundred, see third page of covir.
}

\section{Pride of Michigan.}

\author{
"Our New Strawberry."
}

We place this variety first on our list because it is first in every way. Pride of Michigan is, without doubt, the best and most profitable variety of strawberry ever introduced in the United States.

This grand variety was introduced by us last year. This summer we examined the fruit carefully all through the fruiting season and we say in all honesty that it cannot be beaten. This season made five consecutive years that we have watched the Pride of Michigan and every year it has proven itself to be the most profitable variety we have. We firmly believe that when fruit growers throughout the country try this berry they will want a quantity of them. It is certainis a beauty from every standpoint.

Plant is perfect and berry is perfect. Here are the qualities that make it a most valuable variety:

PRODUCIIVENESS-Will outyield any other strawberry.

COIOR-Dark glossy red (all through).

SEASON OF RIPENING-Second early (ripens with Senator Dunlap.

SIZE-About like Haverland and Glenn Mary. SHIPPING QUAIITY-The best. Very tough skin, and a firm berry.

SHAPE-Rather oblong. Resembles Haverland, never misshapen. (See picture.)

BLOSSOM-Perfect. (A strong fertilizer).

PLANT-Very vigorous and healthy. (A good plant maker).

FRUIT STEMS-Are strong, stand up well and there are plenty of them.

What more could one ask for in the way of qualifications of a perfect strawberry?

We are not asking $\$ 100.00$ per thousand for this new variety as most introducers ask for a new one but we have grown our stock of plants and can sell strictly first-class plants at a very reasonable price.

We confidently recommend this new variety to our customers and friends. It is a money maker. We even urge all to buy Pride of Michigan. . There will be money in it for you. Price, (Postpaid.) $50 \mathrm{c}$ per dozen, $\$ 1.00$ per hundred, $\$ 8.00$ per thousand.

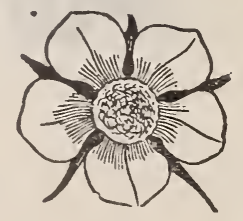


AUGUST IUTHRR-(S)-We believe this to be the best early strawberry we catalog. Last year we fruited about one-half acre of this early berry and were greatly pleased with the results. It is very prolific, comes early and continues to bear till practically every berry reaches a good size. Fruit is very uniform in̄ size and shape. No very large or small ones. Plants are healthy and make good row. The fruit is of good size, roundish, dark red, firm and very easily picked. We would advise all our customers and friends to set August Luther for early berries. \$2.25 per thousand.

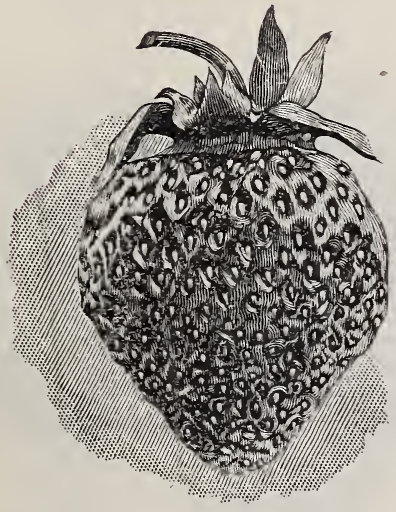

AUGUST LUTHER.

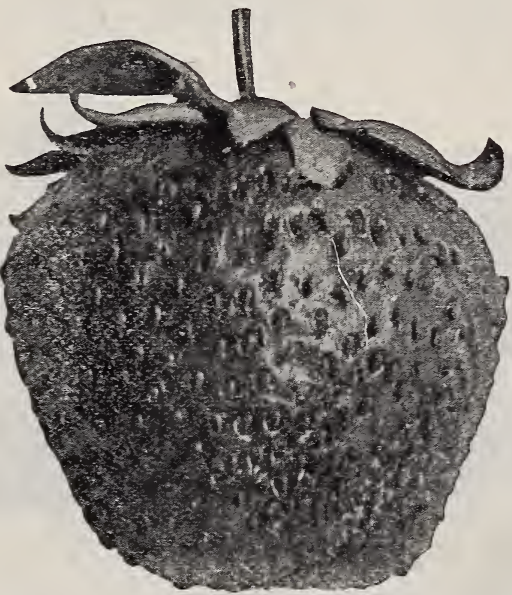

AROMA.

AROMA.-(\$)-This is our best and most profitable late strawberry (witl the possible exception of Sample). We will guarantee the fruit of Aroma to please all who give it a fair trial. It cannot well be beaten for quantity of fruit produced, or in quality of fruit. Plants show no weakness of any kind. Fruit. very large, roundish, conical, rarely misshapen, glossy red, of excellent quality and produced in abundance. It produces twice as much as Gandy and fruit is better in every way. We have grown a large stock of this valuable late variety and have reduced the price to $\$ 3.00$ per thousand.

BRANDYWINE.-(S) - This fine late strawberry was introduced by M. Crawford. We bought a good stock of the plants of the introducer and now have a large stock of fine plants. Brandywine is late, good shape, good quality, good size, firm and productive. If you are looking for a No. 1 canning berry or for table use we would recommend Brandywine. It is extra dark in color, fine flavor, and is an extra good home use and canning berry, besides being a good shipper and profitable market varięty. Try them. We have a good stock of extra fine plants at $\$ 3.00$ per thousand.

BEDER WOOD.-(S) - This variety was originated by Beder Wood, of Illinois. We have fruited it for many years and found it to be a very heavy bearer. of good sized roundish fruit (about as firm as Bubach), season early, a good staminate to fertilize early varieties like Crescent, Warfield, etc. M. Crawford says in his strawberry report: "This berry, all things considered, is the best berry that has even been fruited with me. The plant is a good, healthy grower and sends out a number of large runners. Beder Wood is very deep rooted an 3 will stand a drouth better than most varieties. Will consequently do extra well on a very dry or light piece of ground. We have cleared more money out of Beder Wood planted with Warfield than from any other variety." "The call is neavy for this variety, but we have a large stock of them and have put the price down to $\$ 2.00$ per thousand.

BUBACH.-(P) - This has been a very popular berry for years. We have always considered Bubach a profitable variety. The plant is very large and fine looking but a slow plant maker, the berry large and showy. If you have a nearby fancy market it will pay you to get a large fine looking berry. Bubach will fill the bill. Price $\$ 3.50$ per thousand. 
GANDY.-(S) - This is one of the leading late varieties with fruit growers all over the country. The plant is a strong grower, fruit is large and firm, but does not yield as heavy as some; requires strong soil and fertilizers to do its best. It always brings top prices; it is very late and a big showy berry. Price $\$ 3.00$ per thousand.

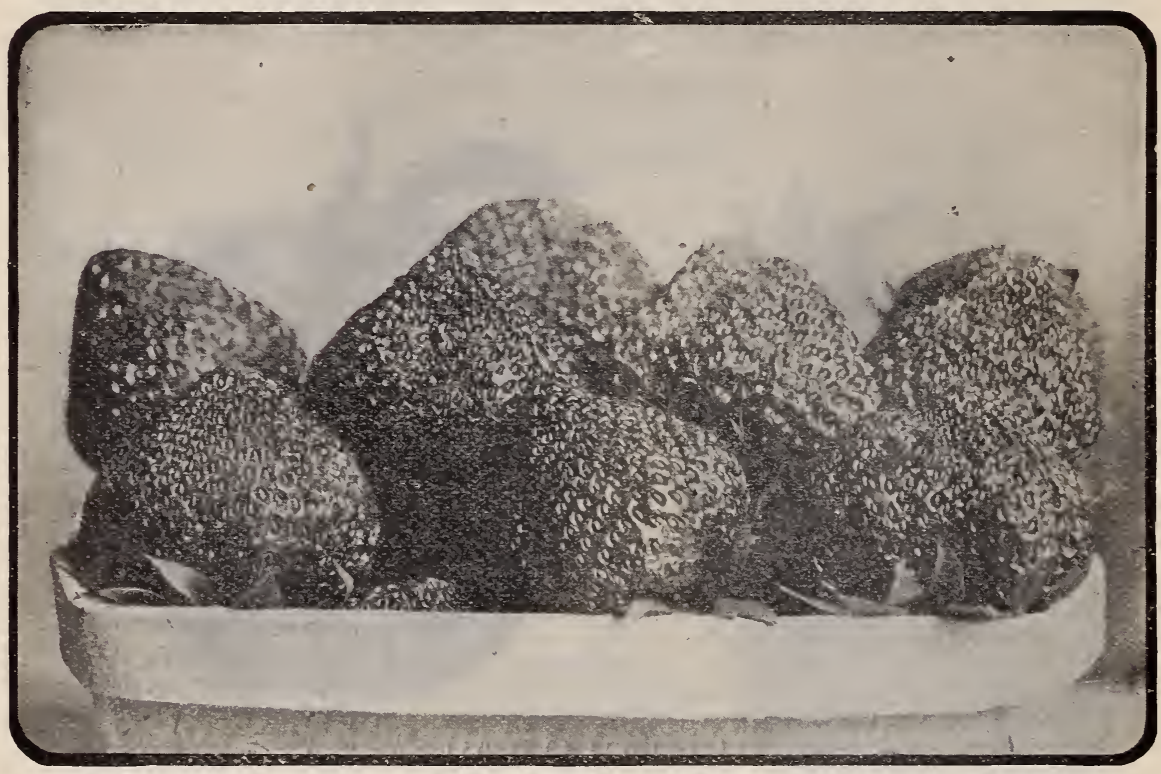

BRANDYWINE.

CRESCENT.-(Improved.)-(P) - The standard of productiveness all over the country; succeeds everywhere; stands neglect best of any, plant small, berries fair size, bright and attractive, not very firm. Many growers consider this the most profitable berry for market. A few years ago a new berry was introduced into this section, which proved to be an improved Crescent. We sell a great amount of this variety every year. We have a full stock of extra fine plants and quote them at $\$ 2.00$ per thousand.

CLYDF.-(S)-This berry has Crescent blood in it and no doubt gets its immense productiveness from that variety. Nearly as large as the Bubach, nearly or quite a week earlier and very much firmer. It is a strong staminate and therefore is suitable for pollenizing medium and medium early pistillate varieties. The plant is very vigorous and healthy, there being no trace of disease about it. The foliage is light green in color and somewhat resembles the Haverland, but is a more upright and sturdy grower. Season of ripening, second early. Its strong plants with an abundance of long roots enable it to withstand drouth better than most sorts. It is a very profitable market berry owing to great amount of good sized berries it produces. $\$ 3.50$ per thousand.

EXCFISIOR - (S) - The plant is a heavy and thrifty grower, not very large but a heavy bearer. There is a great demand for extra early berries and we find that the Excelsior is a very early dark red attractive berry. It is a Southern berry and very profitable for the South. We do not recommend it here, as there are many more profitable early berries. Large stock of fine plants at $\$ 2.00$ per thousand.

GIFI MARY.-(S) - Large and choice, very handsome, and of fine flavor; vigorous and productive. It is as large as the Sharpless and of superior quality. In productiveness it far surpasses the Crescent, not in number of berries, but quarts of berries. Many growers here consider this the most profitable of strawberries. Glen Mary is not only an extra good berry for fancy marliet, but a real money maker for any market. We believe one can pick as many quarts of good berries from Glen Mary as from any other variety and they will sell quickly at a good figure. We recommend this variety to our customers with perfect confidence that it will please them. $\$ 3.50$ per thousand. 
HAVERIAND.-(P)-Exceedingly productive; fruit large and very fine; one of the most popular and well tested varieties; withstands the drouth better than most kinds; color light, season early. Considered throughout the United States as a money maker in most any climate. Demand has always been much larger than the supply. You will not miss it in buying some Haverland. They are a good sure berry. Bought largely for main crop all over the country. They make a good sized fruiting row and mature an immense amount of fruit which is very easy to pick being plainly in sight. We cannot say too much in their favor. Try them and you will agree with us. Price $\$ 3.00$ per thousand.

JOHNSON'S EAREY.-(S)-This is a good early strawberry. Fruit is large for an early berry, dark red and glossy. Very profitable on account of earliness. Johnson's Early is a heavy plant maker, hence our low price. $\$ 2.00$ per thousand.

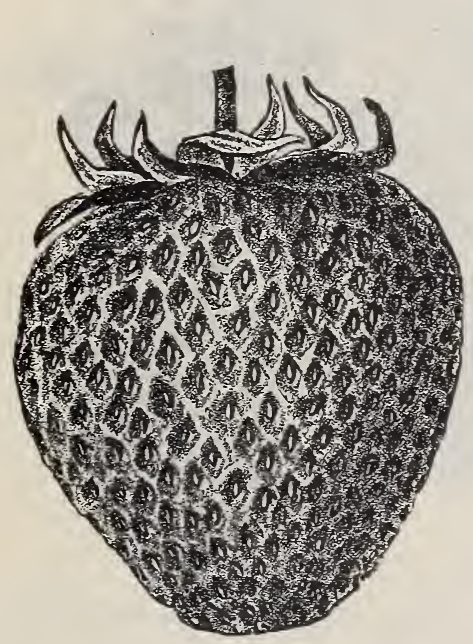

GANDY.

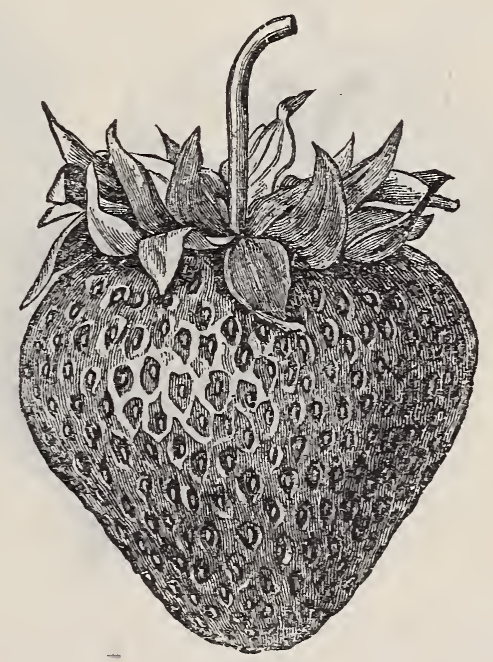

GLEN MARY.

IOVETP-(S)-No person need hesitate to plant this variety for either home use or market, as it succeeds generally in any soil or locality. It is one of the tough hardy varieties that never disappoints the grower. It has a perfect blossom and bears heavily. The fruit is firm, medium to large size, conical, and of good quality. Season medium. We sell large quantities every year for fertilizers for Warfield, Crescent, etc. Price $\$ 2.00$ per thousand.

MICEEI'S EARIY.-(S)-One of the earliest varieties grown, in fact, the earliest we have found. The plant is a very robust grower, strong and healthy, although plant is rather small; one of the best of the early fertilizers, as it blossoms early and late. Fruit is of medium size and good quality. Some growers that grow very early berries make much moniey on this variety alone. It is extra good for light sandy soil. Price $\$ 1.75$ per thousand.

MARSHAIT.-(S)-This is a large, dark red berry. Plant is very large and rank, but slow plant maker. As to its productiveness, it will not yield as large a number of berries as some varieties, but when measured in quarts or bushels it will, in my opinion, be rather above than below the average. Nice, large showy fruit for fancy market. Price $\$ 4.00$ per thousand.

NIC OHMER.-(S)-The introducer says: "After watching the Nic Ohmer three years and hearing how it has behaved wherever I sent it for trial, never having received one unfavorable report on it, I am confident that it is one of the most desirable, if not the very best ever sent out. There is no other in the market or in sight that I would plant with as much confidence. If restricted to a single variety it would be my first choice wihout a moment's hesitation. It is probably not surpassed in healthy, vigorous growth by any variety. It has a perfect blossom. The fruit is of the very largest size, a giant among strawberries. It is never misshapen. Its only departure from the regular roundish conical 

form is when, under high culture, it is somewhat triangular. It is dark glossy

This year we have an extra large stock of plants and have made the price $\$ 3.50$ per thousand.

POCOMOKE.-(P)-This variety was found growing where there had been some Wilson and Sharpless strawberries dumped and is supposed to be a seedling of the old Wilson crossed by the Sharpless. The berry is round, conical and resembles the old Wilson, but is much larger. One of the best varieties in existence, not only for its enormous productiveness, but on account of its beauty, adaptability to all soils, its foliage enduring the dry, hot weather (which quality is rare with some varieties), its large size, its deep red color, its firmness, its

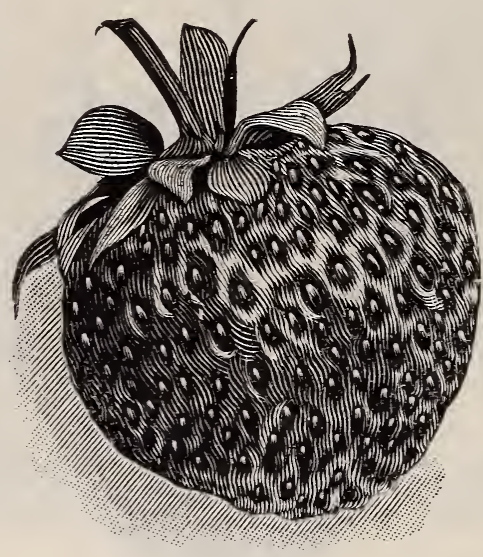

CLYDE。

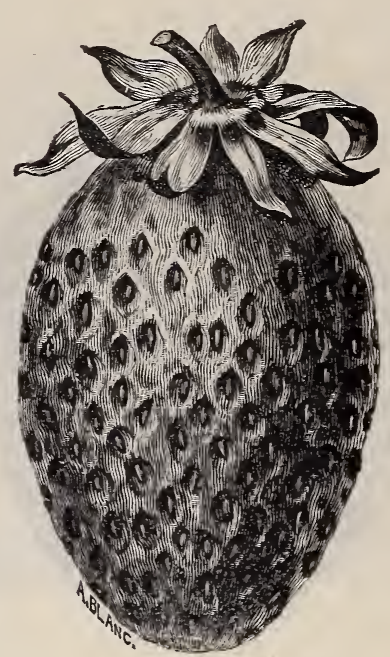

HAVERLAND.

high flavor. The plant is a strong, robust grower, with deep roots and lots of them, perfect blossoms and is an enormous yielder of large red berries. It ripens evenly, and is one of the best shippers yet introduced. This variety is a good one and should be grown as one of our leading market berries. Two years ago we fruited the Pocomoke for the first good test and found it even much better than we had hoped to find it. They will soon be one of our leading market berries. Try a few thousand Pocomoke. We know you will never be sorry. They are fine. Price $\$ 3.50$ per thousand.

We guarantee entire satisfaction with Pocomoke. They are one of the very best and most profitable of strawberries.

PRIDE OF MICHIGAN.-(S)-"The best strawberry grown." Fully described and illustrated on full page in front part of this catalog. (See page 7.) Price, $\$ 0.50$ per dozen; $\$ 1.00$ per hundred; $\$ 8.00$ per thousand.

TENNESSEE PROIIFIC.-(S)-Is one of the good medium early varieties, large size and productive. It is a very vigorous, healthy plant. with never a spot of rust. It has a strong, staminate blossom and is especially valuable as a pollenizer. This variety is largely grown in the vicinity of Norfolk, Va., one of the largest strawberry sections in the world. Tennessee Prolific is an extra good all around berry, and is always profitable with us. You will never be sorry if you order the variety for either home use or market. Price $\$ 2.75$ per thousand.

WARTIIID.-(P)-This is the grand berry for main crop, both for home use and market. We recommend Warfield with enough Senator Dunlap to fertilize them. Warfield has been the leader for years. Fruit is regular shape, choose without hesitation, Warfield with enough Senator Dunlap to fertilize them. Warfield is and has been the leader for years. Fruit is regular shape, dark red and a splendid shipper. We sell more plants of this than of any other variety every year. Resembles Wilson, but is a heavier bearer and better plant 
maker, and better shipper. Plants are small, more like Crescent; requires a strong staminate about every third row for best results. Price $\$ 2.00$ per thousand. (Our sale of Warfield averages about 1,000,000 a year.)

UNCIE JIM.-(S)-(New.)-Plants are large and free from rust. Berry is large, regular form and season is very late. We have fruited Uncle Jim and it seems to be a good all round, berry. We recommend Uncle Jim to our customers as a good, large late strawberry. We think they will please you. Price $\$ 3.50$ per thousand.

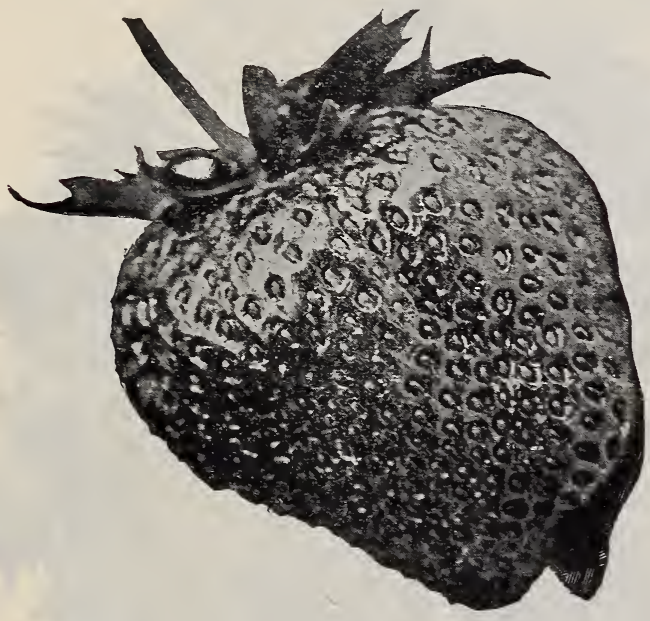

NIC OHMER.

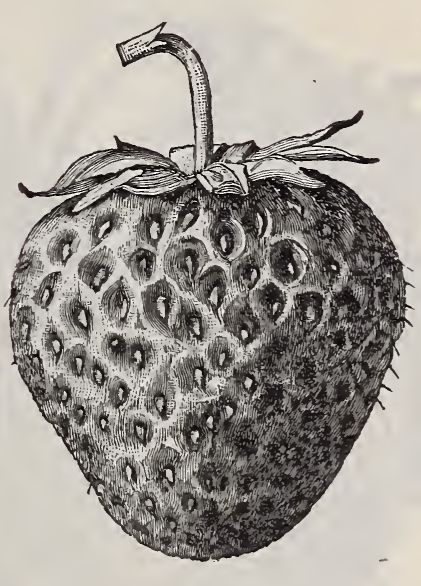

LOVETT.

SFNATOR DUNTAP-(S) - This berry is of the Warfield type, has a perfect blossom, is hardy, productive, a splendid keeper and able to hold its own under any "rough and tumble" methods of culture to which it is likely to be subjected. Senator Dunlap is a very heary bearer of good size even fruit of a very beautiful dark red color. It is a berry to grow for either home use or market. My opinion is that the fortunate ones will be those that get a start at the earliest opportunity. Mr. Crawford says: "The Senator Dunlap is now the greatest all around variety ever introduced." We would advise all to plant Senator Dunlap. I believe it will be our most profitable mid-season strawberry. We fruited one acre of this variety last season, and it was the most profitable acre we had to pick. This variety in our opinion will stay with us as one of the standards. The sale of Senator Dunlap is wonderful considering the time they have been before the people. We quote this variety very low and all should try them for main crop. We expect Senator Dunlap to outsell all other varieties for setting in spring of 1907 . Frice reduced to $\$ 2.25$ per thousand.

SPIENDID.-(S) - I have fruited it several years and can offer it to my customers with great confidence. Plant is a healthy, luxuriant grower, sends out many runners and bears abundantly. The fruit is large and far above the average in quality and appearance. Desirable for either market or home use. This variety has been tested by many berry experts all over the country and has proved itself worthy of its name. We reduced the price to $\$ 2.75$ per thousand.

SAMPIF.-(P)-Season very late. "The Sample strawberry is admired by every one who has seen it. No one who has seen it has been able to criticise it. We have now watched it with the greatest interest for four years and are not able to say that it has a single weak point. Large size and fine quality, quite firm: continues a long time in fruit; the berries are large to the last. It will yield as many berries as the Haverland and will average as large as the Bubach. Colors all over at once. A berry that will do that is the best one found yet. There is no weak spot in it. Foliage perfect, fruit perfect. Needs no petting." I think Sample is the best late strawberry we have (with the possible exception of Aroma). Get a few thousand Sample and fertilize them with Aroma and we guarantee that you will have no kick coming. Our stock of Sample is large, but we will sell all of them at $\$ 3.50$ per thousand. . 
WM. BFIT-(S)-The plant is one of the largest, a very luxuriant grower. Has a perfect blossom and is very productive. The fruit is extra fine. Berries are very large, good shape, good quality, dark red, glossy and attractive. This with the fact that the Wm. Belt is a heavy producer and matures its fruit well and very late makes it a most profitable market variety. It is a money maker with us and would be with you. Price $\$ 3.25$ per thousand.

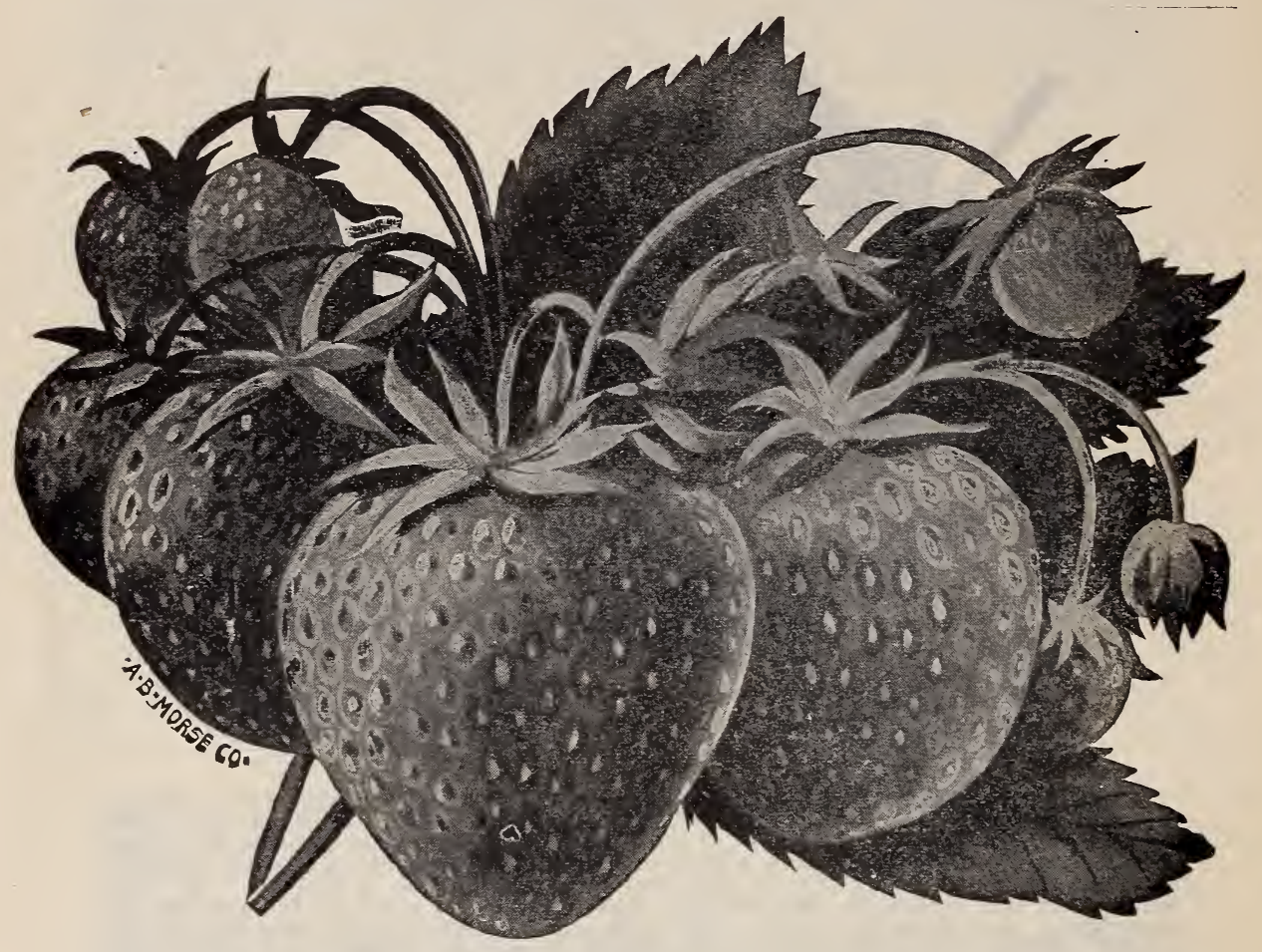

POCOMOKE.

OTHER VARIFTIES. Our customers will notice that several other varieties are missing from our list this year. When a variety fails to "make good" with us after several tests, we throw it out. We have a small stock of a number of varieties not quoted here. If you want anything not listed in this catalog write us.

Varieties marked (P) are "Pistillate," and should have about every fourth row set to some staminate variety for fertilizer. Those marked (S) are "Staminate," and good fertilizers. Set early staminates with early pistillates and late with late, etc. All plants are trimmed and tied in bunches of 25 .

Six of a variety at dozen; 25 at 100 and 250 at 1000 rates. At dozen rates we pay the postage. At 100 rates to go by mail add 25 cents to each 100 ; at 100 and 1,000 rates to go by express or freight, charges to be paid by purchaser. It costs no more to pay on receipt of goods than on shipment, but I have to guarantee all charges, When ordering please state how you wish your plants sent. When you do not state, I use my best judgment for your interest and generally hit it. If not, don't grumble.

Some varieties will be gone before shipping season commences, so we would advise ordering early, if you want your order filled in full and shipped in good season in the spring. We fill orders in rotation as received and booked, so if you expect early shipment we must book your order early. Those ordering before March 1st receive a premium, if mentioned on order sheet. 


\section{Early Orders for Strawberries.}

It is a great saving in expense to many purchasers to have their strawberry plants shipped by freight instead of by express, we would advise ordering early,

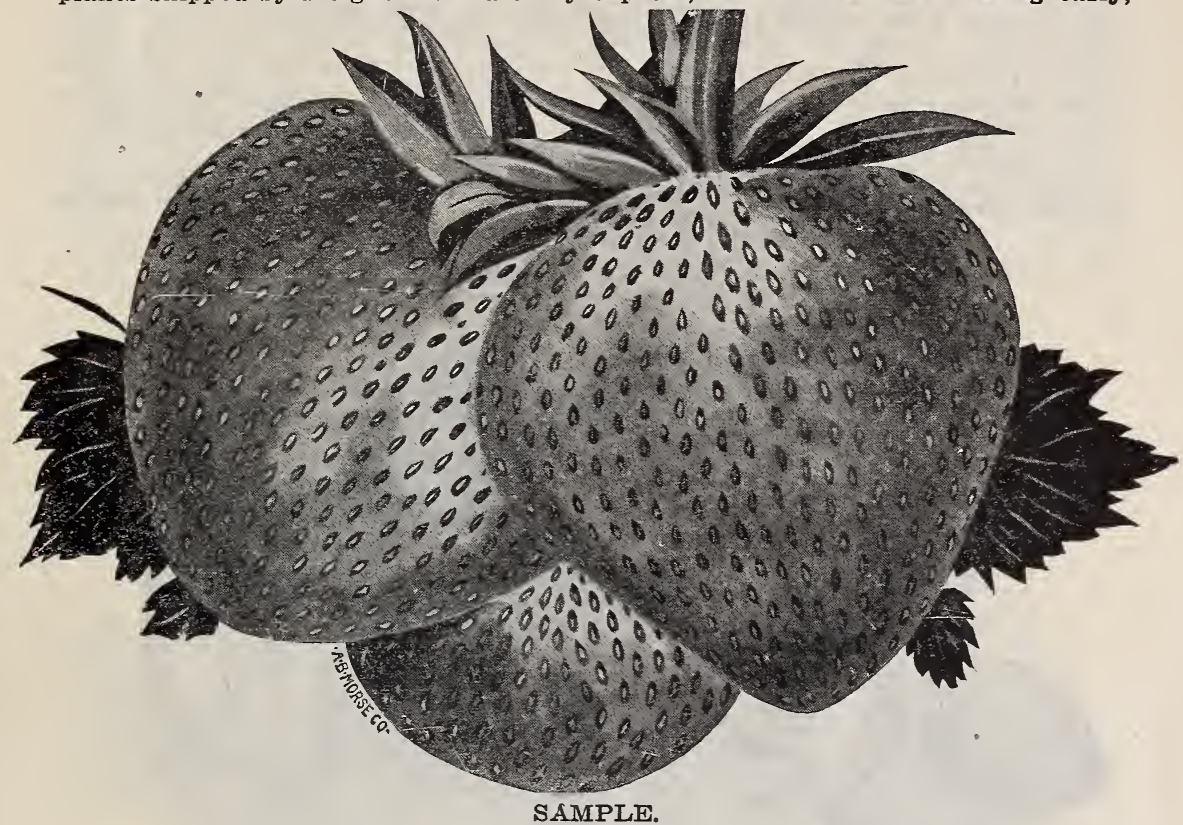

and if the ground is not in condition when they arrive-too wet or not prepared - a very easy method can be used to keep them, which will be a great benefit to the plants as follows: Take each variety, a bunch at a time, cut string, and spread roots very thinly along the side of a shallow furrow, then cover roots

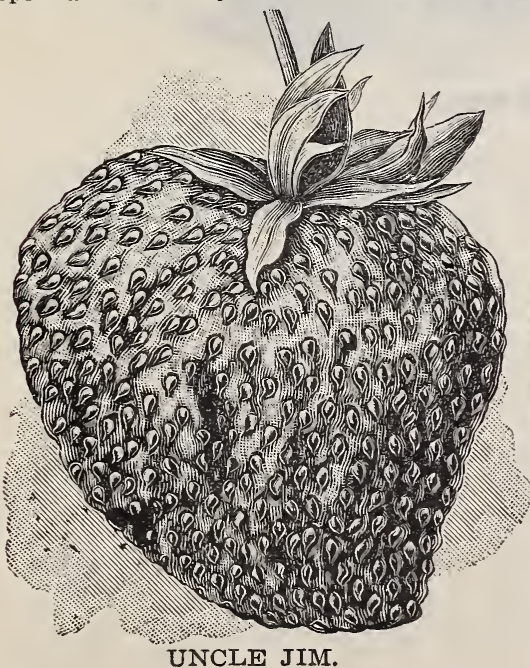

UNCLE JIM.

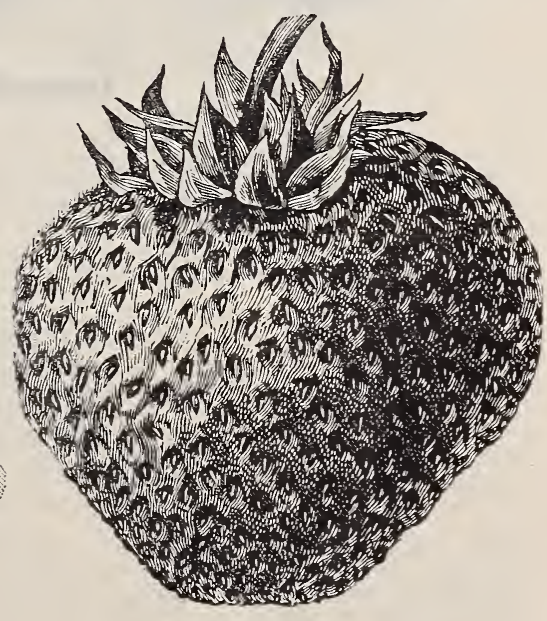

WM. BELT. 
with dirt not higher than the crown of the plants. Give partial shade and if ground is dry water roots only. In a few days they will have taken hold, or rather sent out little white fibrous roots, and will be in better condition for transplanting than at first. This method is sometimes recommended for strawberries even when the ground is in condition, or could be ready to plant when they arrive. So do not wait until late in the season, when the strawberries have started to grow, and then have them shipped by freight, as after they have started to grow it is not safe to send them by freight. We generally advise express shipment for strawberry plants, as by freight there is always some risk of: plants being delayed. If ordered by freight this risk is assumed by buyer, as he is the one benefited by lower rate.

Be friendly and write us. We are here to answer all questions that we are able to answer and we hope to hear from you. Your letter or card will receive prompt, personal attention.

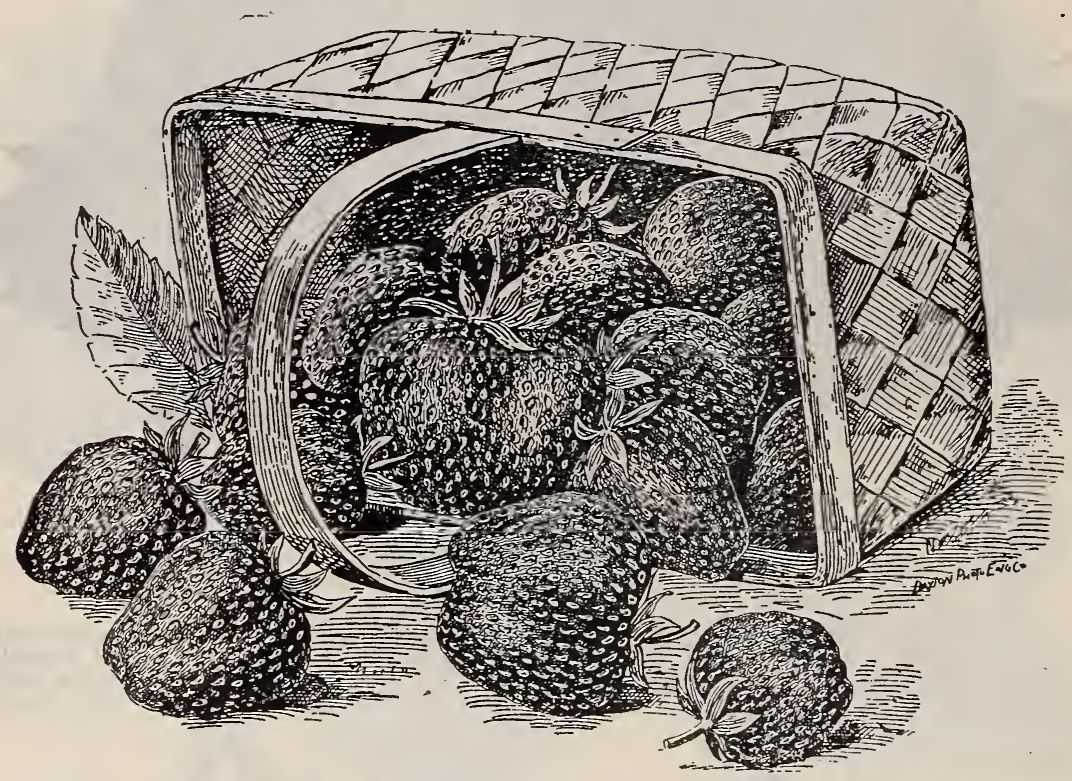

SENATOR DUNLAP. 


\section{Black Raspberries}

25 at 100 , and 250 at 1,000 rates.

CUMBERIAND.-The "Business Black Cap." Largest black raspberry known. This new raspberry was placed upon the market after having been thoroughly tried for a long period of years. It is now offered with the full assurance that it is the most profitable and desirable market variety $\forall \in t$ known, because of its immense size, firmness and great productiveness, weil entitling: it to the above designation, "The Business Black Cap." Its qualities we take up in what we consider the order of their importance, mentioning first of all that of

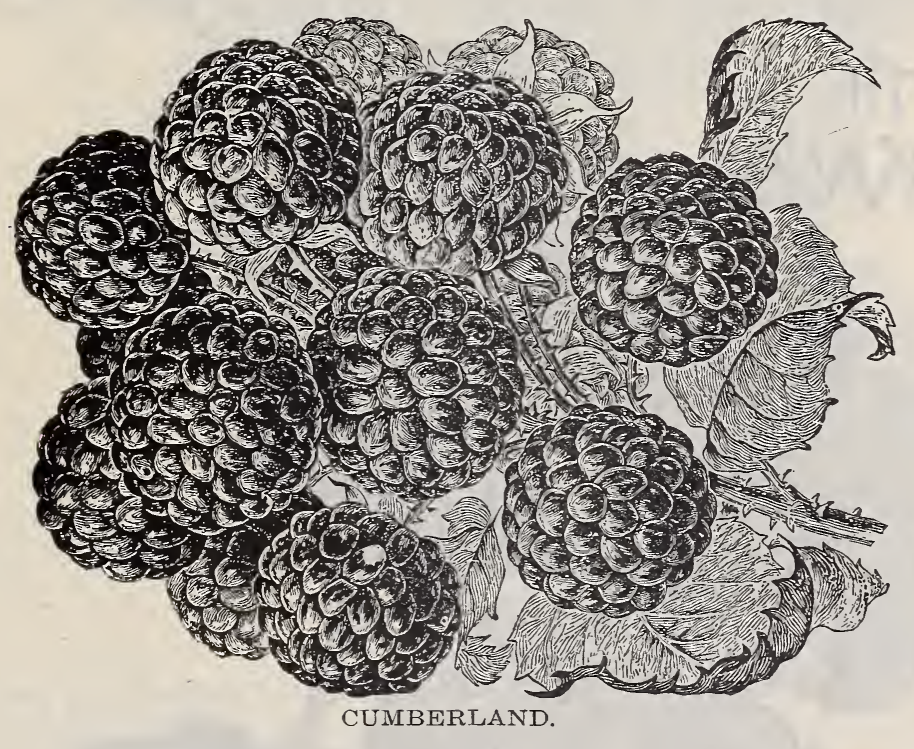

Hardiness.-The Cumberland has undergone a temperature of 16 degrees below zero unprotected, without injury-a temperature which badly crippled similarly situated plants of Gregg, Shaffer, Cuthbert, etc. In this most important respect, therefore, this new berry will not be found wanting.

Prounctiveness.-The Cumberland is of wonderful productiveness, producing regularly and uniformly very large crops. Bears more fruit than any other variety.

Quality.-In quality it is similar and fully equal to the Gregg, which has always been considered the finest of the black caps in this respect.

Ripens before Gregg. We bought our stock of plants of the introducers. Last season Cumberland again proved itself much better than all other varieties of black raspberries. You will never regret getting Cumberland.

We would rather have one acre of Cumberland than two acres of any other variety of black raspberry. This is a broad assertion, but we honestly belfeve Cumberland is that much better than any other cap variety. This year we have a large stock of fine plants and are quoting them at $\$ 1.25$ per hundred; $\$ 10.00$ per thousand.

GREGG.-(Cap.)-Very large, wants good soil to produce best results, fruit very fine and covered with bloom. It is the leading market variety all over the country, best for evaporating of any variety as it is said to give more pounds to the bushel of any kind. A good all round late blackcap. Gregg will not disappoint you. Very well and favorably known in every fruit district. 85 cents per hundred; $\$ 7.00$ per thousand. 
CONRATH.-(Cap.)-This is a very profitable blackcap. Plant is very productive, fruit large, good flavor, firm, nearly coal black and parts readily from core. Although early it has a long season and holds its size well to the end. 85 cents per hundred; $\$ 7.00$ per thousand.

FURFKA.-A fine early blackcap in every particular. We have grown Eureka berries one inch in diameter. Unexcelled for fancy fruit. $\$ 1.00$ per hundred; $\$ 8.00$ per thousand.

PAIMrR.-(Cap.)-One of the earliest to ripen and matures its whole crop in a short time. The berries are jet black and of good quality. It is a luxuriant grower, healthy, hardy and wonderfully productive. Profitable on account of its extreme earliness. Our stock is limited. Price 85 cents per hundred; $\$ 6.50$ per thousand.

KANSAS.-(Cap.) - This variety is now a general favorite with growers all vver the country, Ripens just after Souhegan; jet black, firm, handsome and of the best quality; bush a strong grower, holds its foliage until frost; stands drouth and cold, very productive. We find it even better than we expected. It is about as large as Gregg, early and very productive. Strong, healthy canes, makes plenty of strong tips. Price 85 cents per hundred; $\$ 7.00$ per thousand.

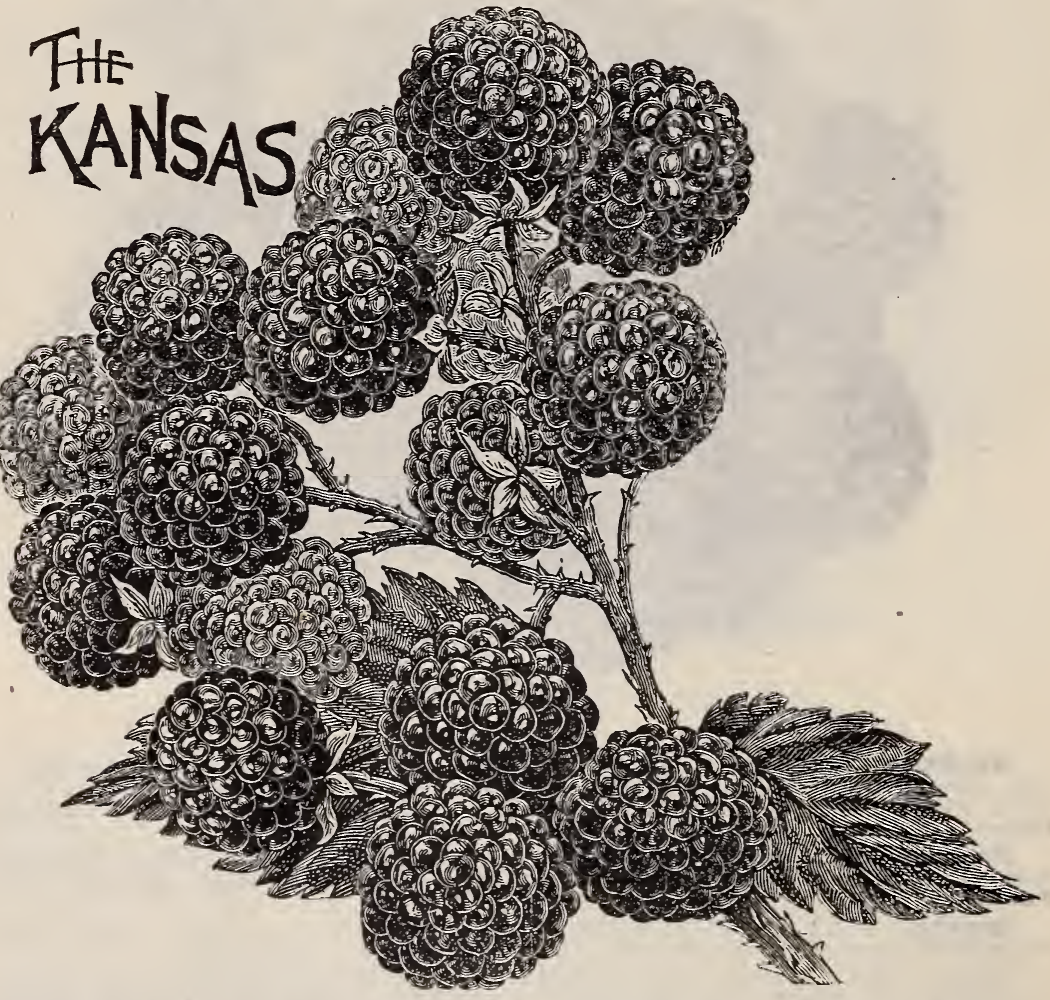

CorumbiaN.-(Purple Cap.)-The Columbian is a variety of the Shaffer type of remarkable vigor and productiveness. It is very hardy and propagates from tips. Fruit very large, often an inch in diameter, shape somewhat conical: color dark red, bordering on purple; adheres firmly to the stem; seeds small and deeply embedded in a rich juicy plup with a distinct flavor of its own, making it a he have an extra fine stock of this variety. I consider it much better than shaffer on account of its hardiness and vigor of cane, and will dry. on the bush if not picked. $\$ 1.50$ per hundred; $\$ 12.50$ per thousand.

Cardirar.-(Purple Cap.)

Described as follows: Its growth is of the strongest, and canes being of very hard wood, with red bark and a very few small thorns, one between each leaf- 
practically thornless. It propagates from tips. Its leaves are thick, short, broad and deeply wrinkled, entirely free from all.traces of anthracnose or other diseases. Its productiveness is a surprise to fruit growers. The fruiting spurs on bearing wood are a foot or more long, and new ones come from near the stump from two to three feet long, loaded from the bottm up, and the fruit is well up for quick picking. The berries are large, dark, firm as to texture, with an agreeable, pure, rich flavor, which is brought to its highest perfection when canned or cooked into pies. Their season is rather late and they hold on well. $\$ 1.50$ per hundred; $\$ 12.50$ per thousand.

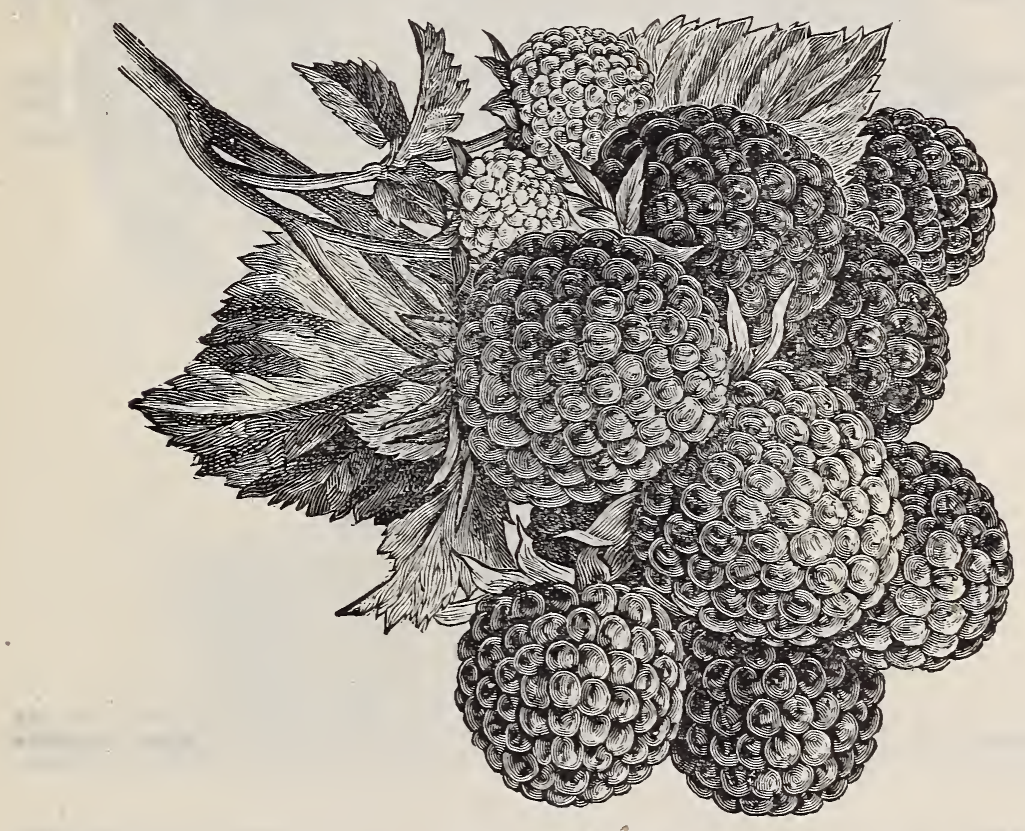

THE HAYMAKER.

THE HAYIMAKFR.- (Purple Cap.)-Not so dark as the Columbian or Shaffer and much larger and firmer than either of those varieties, never crumbles and stands up well in shipping. Sample crates have been shipped to distant points with entire satisfaction. It is a berry to grow for either home use or market. The originator has found it the most piofitable berry ever raised for market, and has never yet been able to supply the local demand. So much a favorite has the Haymaker become that local growers have said that it has ruined the sale of other varieties. Very popular as a canning berry.

Prof. W. J. Green, Ohio Agricultural Experiment Station, Wooster, Ohio, writes: "The Haymaker is a purple cap variety of recent origin. Although resembling the Columbian, it is quite distinct from that variety in many particulars. It appears to be as much superior to the Columbian as the Columbian is to the shaffer. The plants are extremely vigorous and uncommonly prolific; the berries very large purple in color and quite firm. Judging from its behavior here, and on the grounds of the originator, it is an uncommonly promising variety, and will no doubt prove to be valuable for canning."

Crawford writes: "I have had every opportunity to become acquainted with the Faymaker Raspberry, having fruited it on my own place several years, in addition to careful examinations on the originator's place. Besides being a vigorous grower, perfectly hardy, and free from any appearance of disease, it is the most productive variety I ever saw. It is of good size and equal to any of the purple varieties in flavor. I expect it to be a great favorite with those who grow raspberries for profit."-M. Crawford.

It certainly has four points of superiority, viz.: vigorous growth, hardiness, productiveness and quality. I believe Havmaker is a good thing to have and we expect the demand will be very heavy. Price is where they will go fast. $\$ 1.75$ per hundred; $\$ 15.00$ per thousand. 


\section{Red Raspberries}

MIIIFR is early, very hardy and does not winter-kill. This fine early red raspberry is, for an early berry, what the Cuthbert is for a late one. The very best there is. Shipping qualities are perfect. Makes a healthy growth of canes. If you want the best early red raspberry, get Miller. You won't be sorry. 65 cents per hundred; $\$ 4.50$ per thousand.

CUTHBERT.-Leading late market variety all over the country; strong grower, very productive, fruit firm, large size, and of best quality; season medium to late. If you want an all around late red raspberry, plant Cuthbert. I believe we make more clear money from two acres of Cuthbert every year than

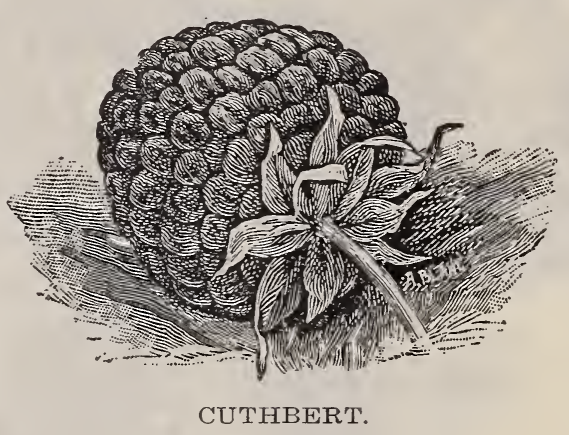

from any two acres we have. Considering the fact that we cultivate about one hundred acres, that is saying a great deal for Cuthbert. They are money makers for us, they would be for you. Price only 75 cents per hundred; $\$ 5.00$ per thousand.

KING.- This is a new red raspberry. Unites large size, beautiful color, firmness and high quality of fruit with productiveness. Vigorous growth and hardiness of cane. Its season is the earliest, its fruit of the brightest crimson; there are none brighter or more beautiful, and of the very best quality.

In productiveness, vigor of cane, hardiness and endurance in heat and drouth, it is second only to the purple cane varieties (Cardinal and Columbian). I believe it worthy of all that can be said in its favor. Price $\$ 1.50$ per hundred; $\$ 13.00$ per thousand.

THOMPSON'S EARIY PROIIFIC.-A seedling red raspberry originated by M. T. Thompson, who claims it to be one of the best early sorts. Some of our neighbors raise Thompson's Early quite extensively and say they make good money from them. 60 cents per hundred; $\$ 4.00$ per thousand.

IOUDON.-This raspberry ripens moderately early and holds out very late; it is highly productive, claiming to excel all other red raspberries in this respect. Firm as dny other raspberry, a good shipper; large, of superior quality, and an attractive crimson color. The bush is thornless and hardy. We list it very low this year, viz.: \$1.no per hundred; $\$ 8.00$ per thousand.

BRANDYWINE.-A grand well tested variety. We recommend to all as a very profitable red raspherry. $75 \mathrm{c}$ per hundred; $\$ 5.00$ per thousand.

THE EATON.-A new red raspberry that is entirely distinct from all other varieties. In character of growth, in size, color, firmness, quality, and yield of fruit, in length of season, and in all strong points of merti it stands unequaled and alone. A variety that is a tonce healthy in root and foliage, and hardy, coming through our most severe winters in prime condition. A strong, not tall and 


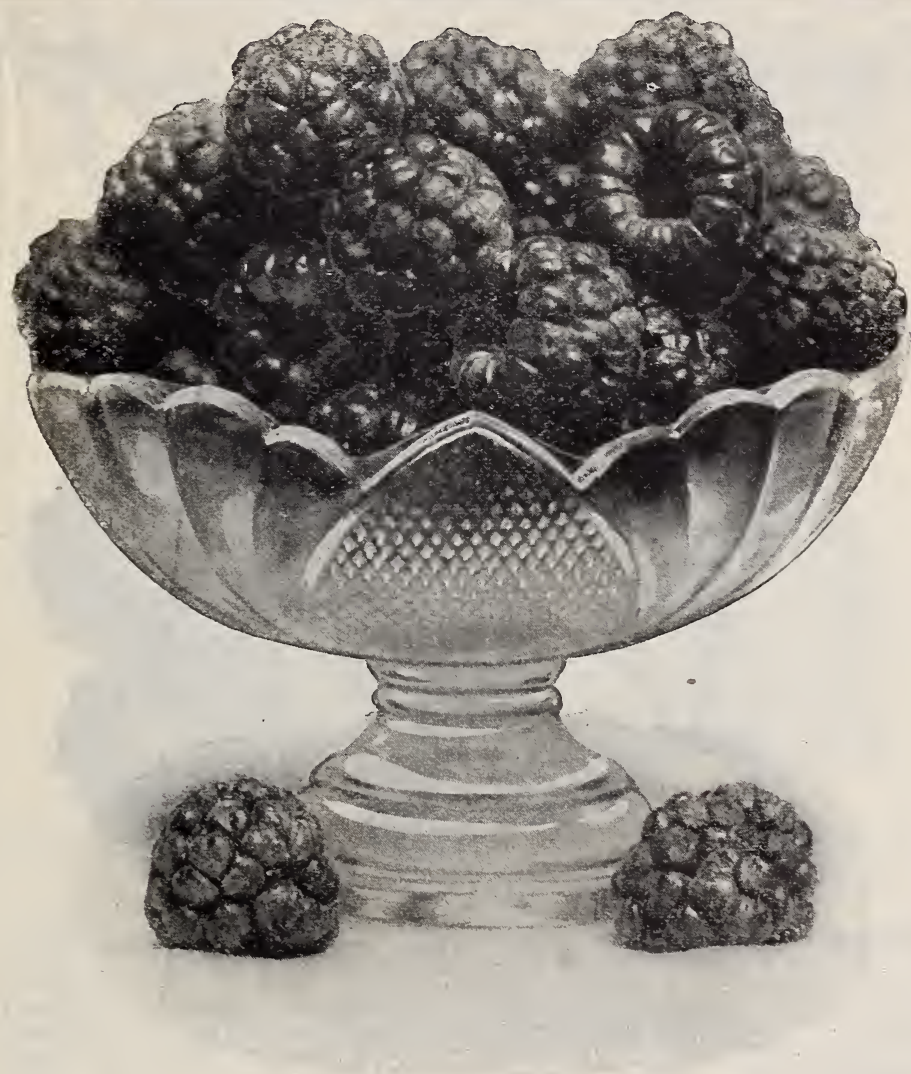

EATON

slender, but a sturdy grower. Throwing out many laterals and fruiting to the tips, and from every lateral-a sight to see. An immense cropper, by for outyielding any red raspberry we have ever seen, while the f'ruit is extraordinarily large and handsome, firm, and of the finest quality."

Price, $20 \mathrm{c}$ each; $\$ 2.00$ per doz.; $\$ 10.00$ per hundred.

\section{Blackberries}

Should be planted in rows six or seven feet apart, three to four feet in the row.. 25 at 100 , and 250 at 1,000 rates.

mIDORADO.-We place this variety ahead of all others without a moment's hesitation. It is the greatest blackberry ever grown.

Eldorado is as hardy as the Sryder, twice as large and of much better quality. When you get one like that you have a berry that cannot be beaten. Eldorado has never been known to winter-kill, even in northern Michigan and Wisconsin. lior home and market use we reconmmell Eldorado above all others. We consider it the best blackberry we ever fruited in every way, and we have grown them all. Our Eldorado field is a sight to see in blossoming and fruiting time. The fruit is good size, firm and of the very highest quality.. Very profitable, as 
it needs no protection in winter. We bought our first stock of the originator, consequently our stock is genuine. Our plants this year are the finest we ever raised, and our stock is the largest, but we expect to be sold out of this variety by March 1st. Try them. Order now! Price this year $\$ 1.50$ per hundred; $\$ 13.00$ per thousand.

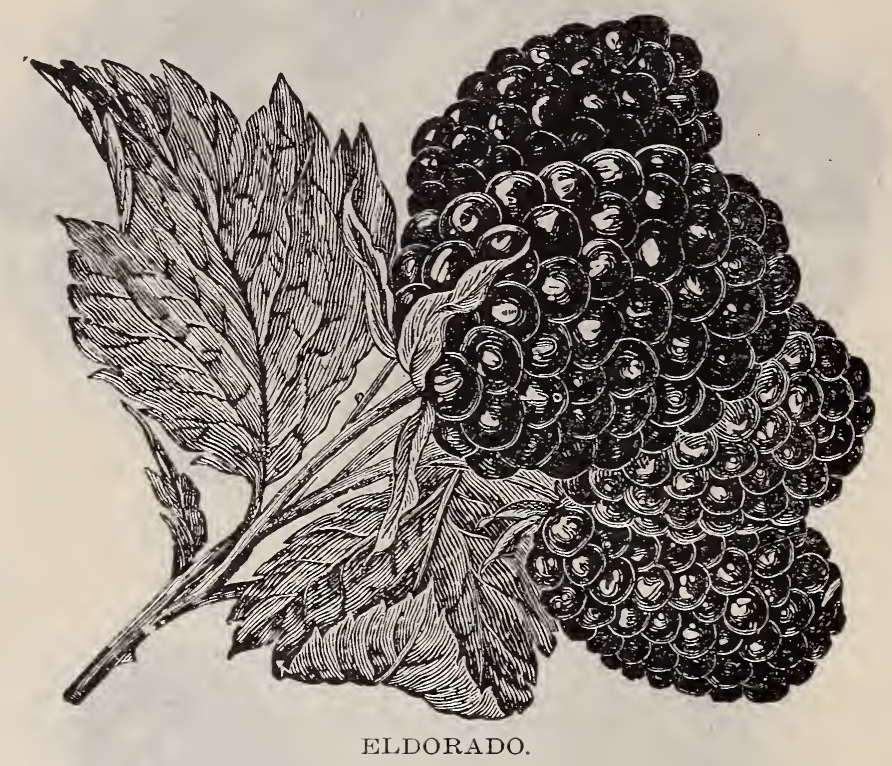

WIISON'S FARIY.- One of the largest and most productive of the early sorts, produces fruit in large clusters, sweet as soon as black, holds its color well after picking, needs protection at the north. It is the best shipper there is. Very profitable. In spite of the fact that Wilson requires protection here in Michigan there are more than twice as many acres of them in bearing as any other variety of blackberry. Price 85 cents per hundred; $\$ 7.00$ per thousand.

MINNFWASKI. (New)-Large, productive and quite hardy; fruit round and of very good quality; bush a rank grower; desirable for market or home use. Our Minnewaski continues to be a great favorite with us. The longer we grow it the better we like it. $\$ 1.25$ per hundred; $\$ 10.00$ per thousand.

SNYDFR.-Very popular for the north and northwest on account of its extreme hardiness; wonderfully productive, size medium, fruit juicy and sweet, without the hard core of many sorts, canes remarkably strong and thrifty, more largely planted than any other of the iron-clad varieties. We have a heavy demand for them every year; season early. $\$ 1.00$ per hundred; $\$ 8.00$ per thousand.

FRIE.-Resembles Lawton in form and productiveness, but ripens earlier and is "iron-clad." Fruit shiny, jet black, delicious flavor. Erie is one of the most profitable of blackberries. It is a medium early blackberry of good sized, fine flavored fruit. They are nice looking berries and always bring good price on any market. You will never regret buying Erie plants. Price \$1.25 per hundred; $\$ 10.00$ per thousand.

Extra fine Root Cuttings of Erie, $\$ 1.50$ per hundred; $\$ 11.50$ per thousand.

FARIY KING.-An extra early blackberry, exceedingly hardy variety of great merit. Needs no winter protection, always producing large crops. Canes of a strong growth, as hardy as Snyder and very prolific. It is larger than Early Harvest, and its delicious sweetness renders it of special value for home use or market. It is also free of double bloom and other disease, will go through hard spring frosts at blossoming time without injury. Those who have tried this variety are well pleased. We recommend them highly for home use.

The Michigan Experiment Station reports them as follows: trial."

"Early King. Large, vigorous and productive. They are worthy of extensive

$\$ 1.25$ per hundred; $\$ 10.00$ per thousand. Extra fine plants. 


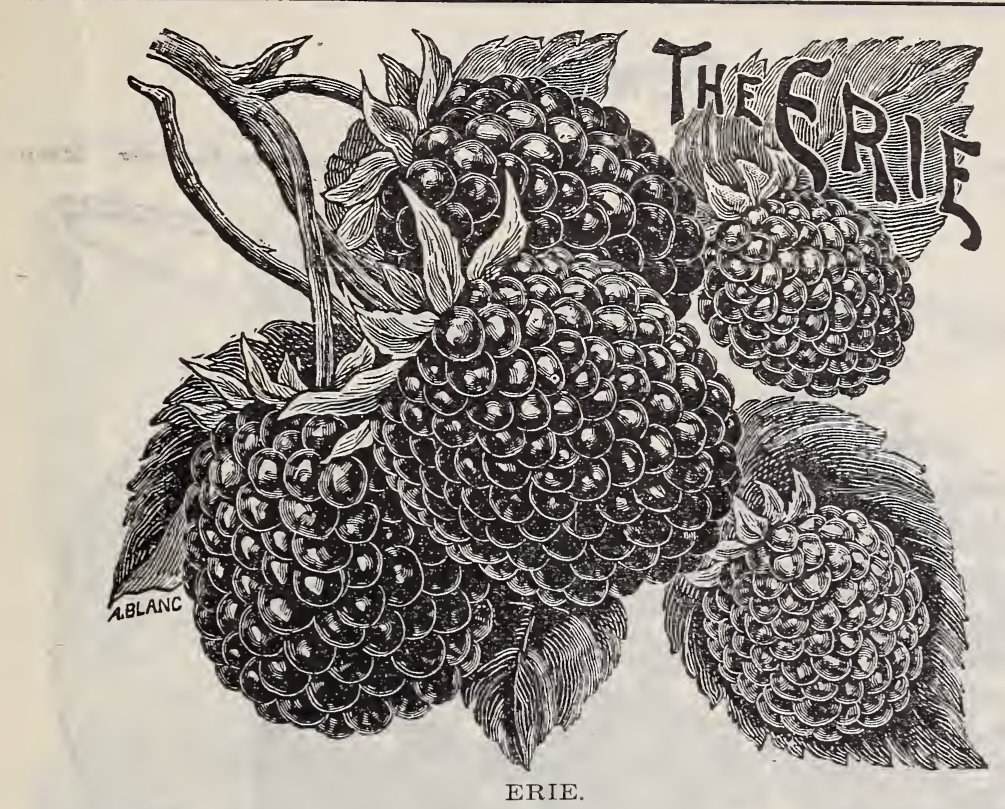

KITTATINY.-Good for main crop. Berries large, handsome, delicious flavor, canes strong, erect and very productive; season medium. Is liable to rust on low ground. It is a very heavy yielder of large, nice handsome fruit. 75 cents per hundred; $\$ 6.00$ per thousand.

IAWTON.-Too well known to need much description here. A hardy, productive, large, late blackberry. Stock is limited. $\$ 1.00$ per hundred; $\$ 8.00$ per thousand.

EARIY HARVEST.-One of the earliest blackberries in cultivation; a compact dwarf grower, fruit rather small and of good quality, heavy bearer. Its extreme earliness makes it a profitable variety; not hardy. Has to be laid down. Blossoms stand the spring freeze best of all. 65 cents per hundred; $\$ 5.00$ per thousand.

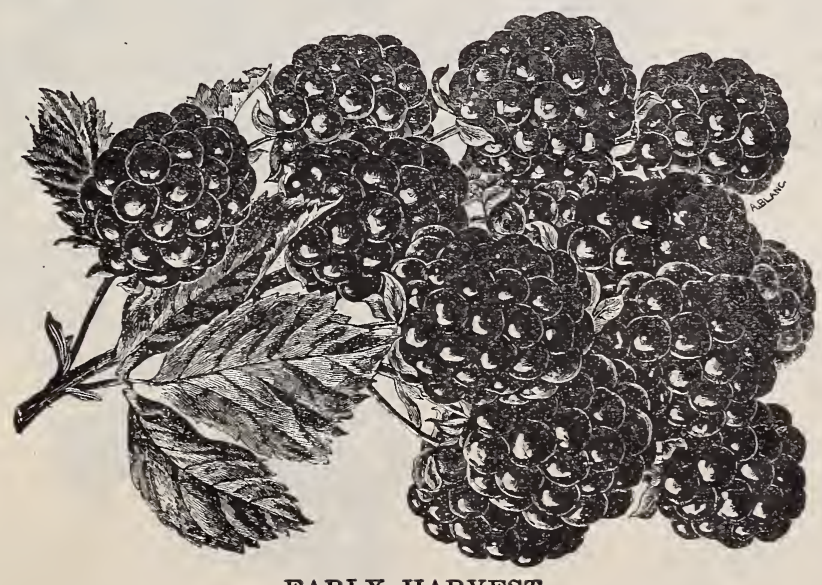

EARIY HARVEST. 


\section{Dewberries}

Plant in rows six feet apart with plants three feet apart in the row. Keep the soil well cultivated.

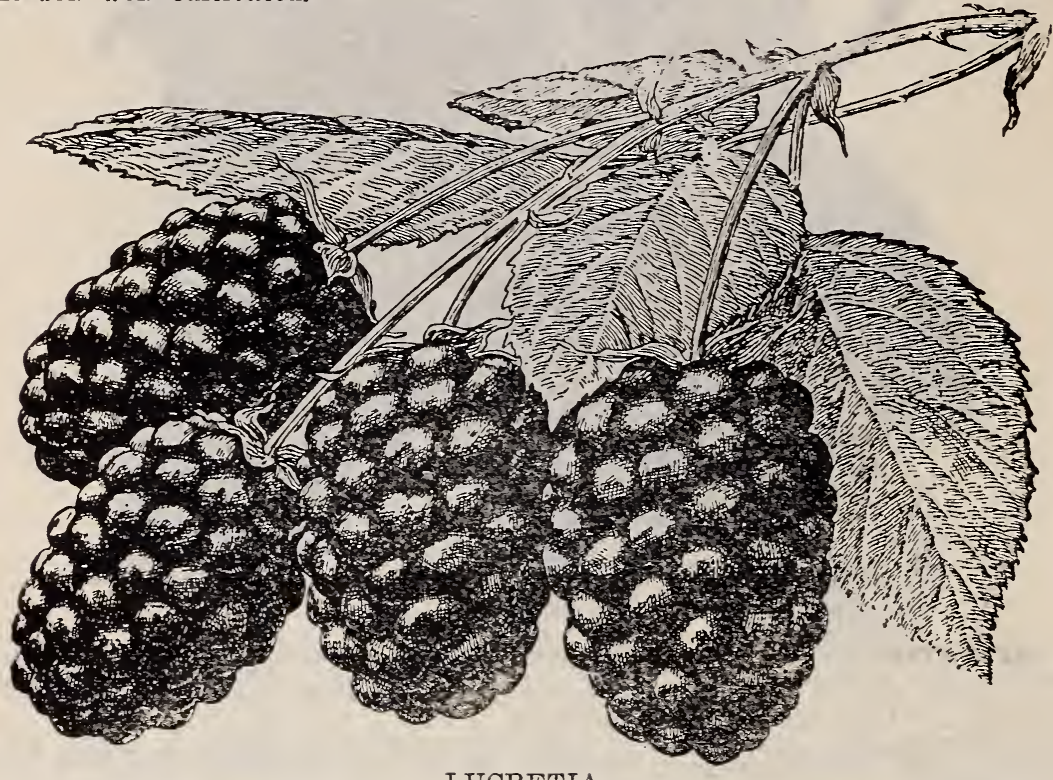

\section{LUCRETIA.}

IUCRETIA.-Claimed to be the best of the blackberry family. Berries are far larger and incomparably better than any blackberry; of unequaled excellence; soft, sweet and luscious throughout, of brightest glossy black color. The Lucretia Dewberry has received the endorsement and highest praise from the best horticulturists in the country. Its eminent success in all soils is somewhat phenomenal in small fruit culture. Its trailing habit renders it less liable to winter kill. Propagates from the tips.

Dewberries are very profitable fruit to have as they come into bearing before blackberry plants and bring a good big price. Price $\$ 1.00$ per hundred; $\$ 8.00$ per thousand.

PREMO.- Much like Lucretia, but a week or ten days earlier. Main crop off before Lucvetia commences. Comes early, ahead of blackberries and brings a good price, Our stock is limited. $\$ 1.50$ per hundred; $\$ 12.50$ per thousand. 


\section{Currants}

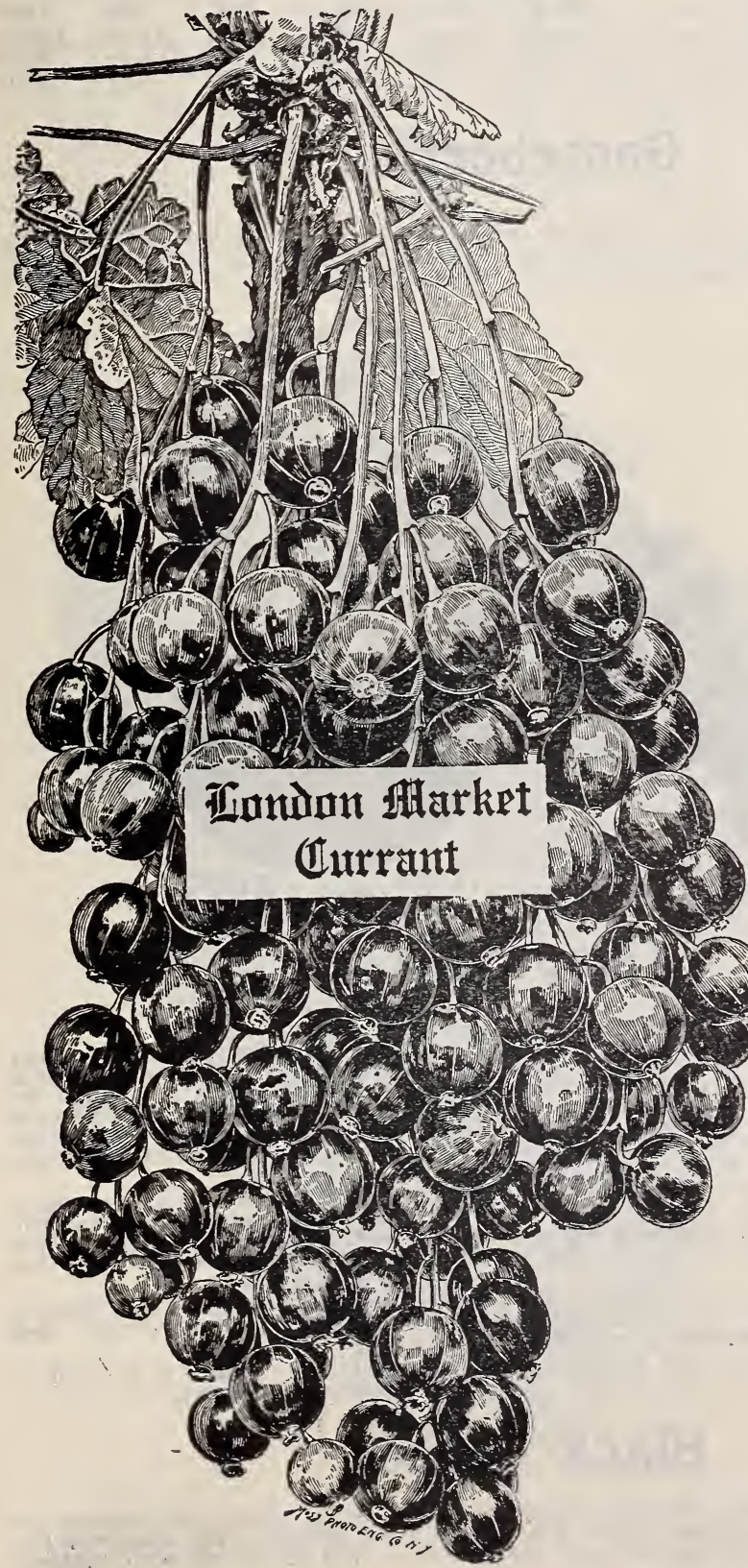

A cool moist lofor this fruit, and for this reason it does well when planted by a fence, being benefitted by the partial shade. Plant in rows four feet apart and the plants three feet apart in the rows. Keep the ground mellow and free from weeds.

IONDON MA RKET is the best red currant we have fruited. A fine, new variety, a strong grower, large fruit and very productive. Holds its foliage late and is not liable to attack of worms and borers We have fruited three acres of $\mathrm{th}$ is variety four years, and each year they produced a wonderful crop of fine fruit. We advise all to buy London Market. It is the very best currant we ever saw.

R I D CROSSJacob Moore, the originator says: 'Red Cross clusters are long and have wellnecked berries double the size of Victorias, and far superior to Cherry or Victoria. Nothing wil compare in quality with Red Cross but White Dutch, which is too small. Red Cross was first fruited in 1899 . I have seen the fruit growing in such masses as to hide the upper branches from view. It is later than Cherry: the plant makes twice the growth of Cherry. and yields two or three times as much fruit. I recommend it with confidence. I consider Red Cross oue of the best of the new currants."

CHFRRY.-A very popular red currant grown all over the country for home use and market The berry and bunch are very large and there is alwavs a good crop of fruit every year. They are most too well known to need much of a description here. 


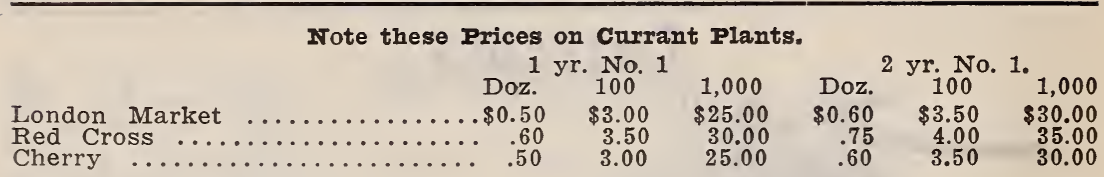

\section{Gooseberries}

DOWNING.-We have a fine stock of the most popular all around berry for both home use and market in the country to-day. Plants two years old, No. 1 , $\$ 1.65$ per dozen; $\$ 10.00$ per hundred; $\$ 80.00$ per thousand.

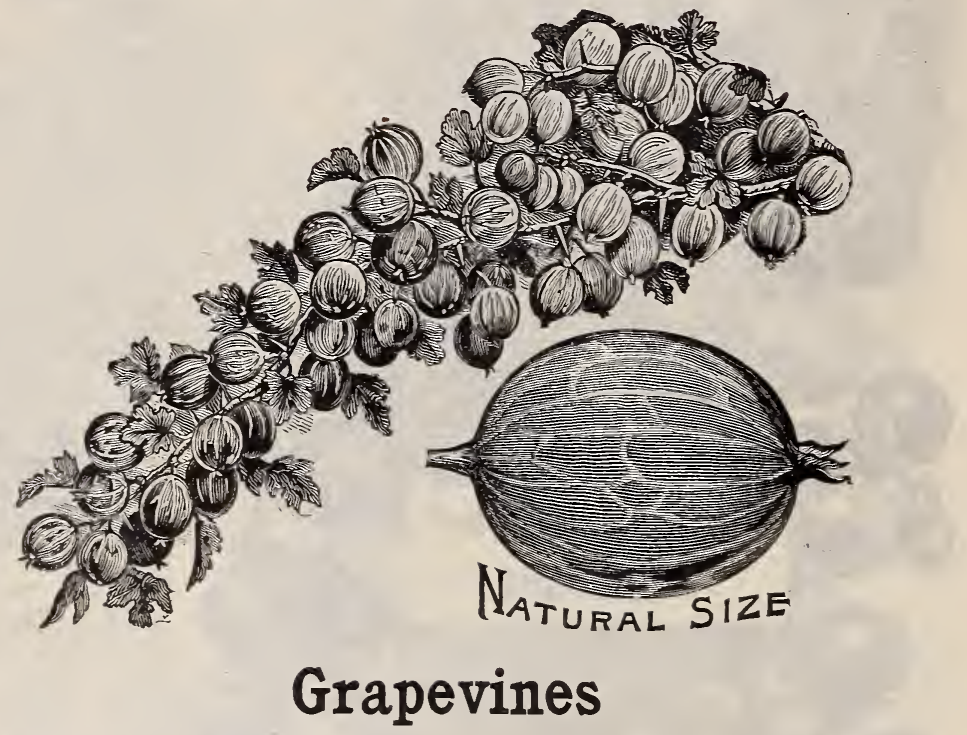

Grow Grapes and Make Money.

The grape is a very satisfactory fruit to raise, as it can be put to so many different uses. It can be confined to a stake, bound to a trellis, trained over an arbor or to cover a large building, and under all conditions will yield its delicious fruit. No fruit will give better returns for close attention and kind care, and good returns can be had from soils that are unfit for any other crop. The side of a hill freely exposed to the sun and air is an ideal place for grape culture, whether the soil be sandy, clayey or loamy.

The increased and still increasing demand for grape juice in our hospitals, etc., etc., for a beverage has made the call for grape vines very heavy for the past two or three years. There is big money in growing grapes and many people are beginning to realize the fact. The market cannot be overstocked with this fruit.

They can quickly be made into juice for which there is a demand that always exceeds the supply and is something that will keep for years and years. Get a grape vineyard started this year, sure.

Grape vines will grow and do well on light sand or clay where it is hard to raise a crop of grain or other fruit. Look at our prices this year.

\section{Black Grapes}

CONCORD.-A large, purplish black grape, ripening about the middle of September; vines remarkbly vigorous and free from disease; the standard for productiveness and hardiness all over the country. We advise all who contem- 
plate setting grapes, to plant Concord for main crop. They are the best market grape we ever raised. Our stock is extra large and thrifty and will please you.

\section{Our prices are very low on Concord.}

WORDEN.-In brief, an improved Concord; being large in both bunch and berry, handsomer, nearly two weeks earlier and of better quality. Very choice and-reliable. Worden will not yield like Concord and so are not planted so extensively for market. They are an extra good grape for home use. By far the best flavored black grape we havê. Note our low prices on this valuable variety.

MOORE'S FARIX.-Bunch large, berry round (as large as the Wilder or Rogers' No. 4); color black, with a heavy blue bloom; quality better than the Concord; the most profitable market sort. Moore's Early has been exposed to a temperature of more than 20 degrees below zero without injury, and it has been entirely exempt from mildew or disease. Its earliness makes it desirable for an early crop, and more particularly adapts it to New England and the northern portion of the United States.

We have a few thousand extra fine large vines.

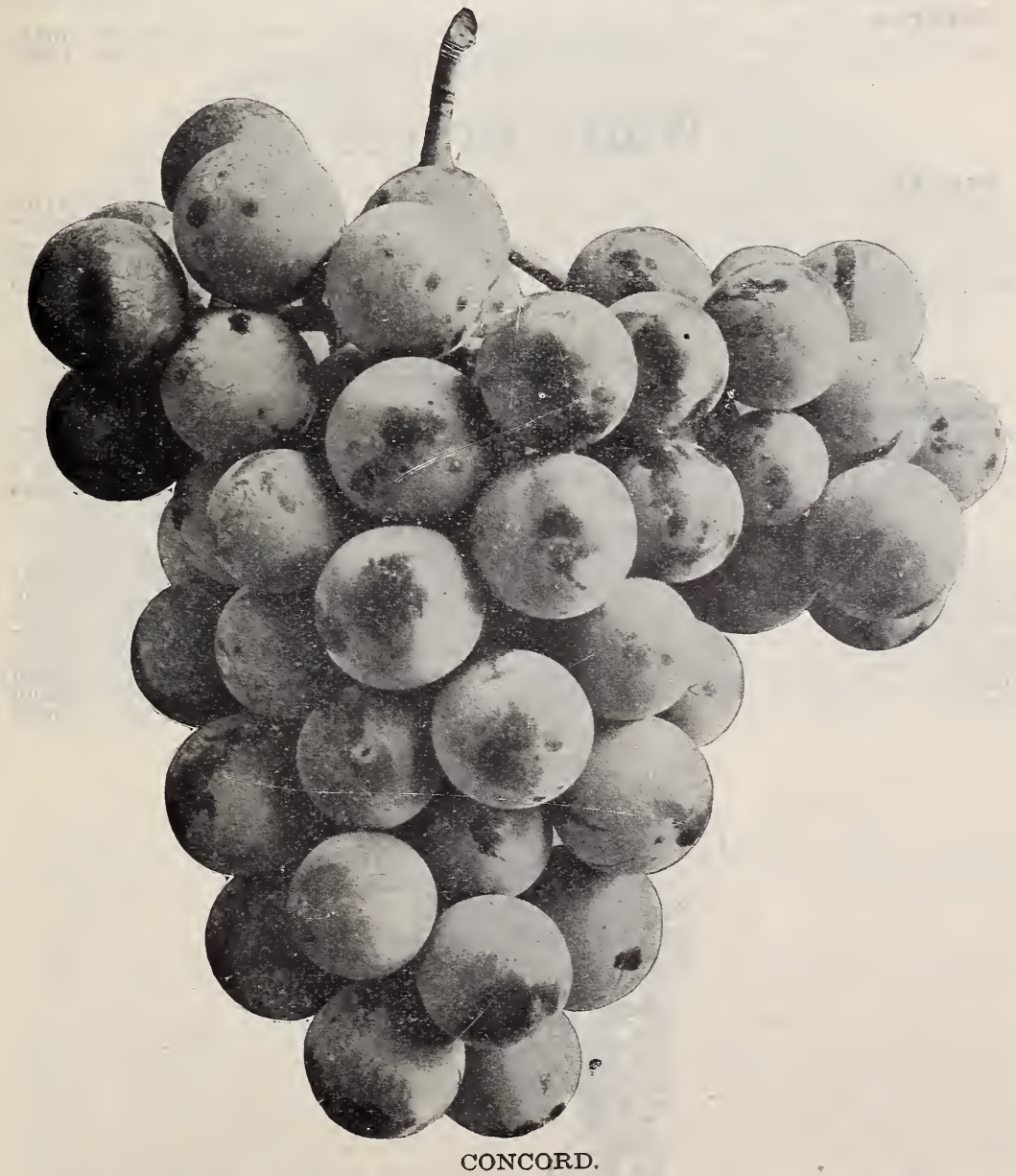

It is very nice to have a few grapes ripe and ready to eat before your neighbor. Moore's Early wil please you. We have reduced the price considerably this year. 
CAMPBRII'S FARIY.-A wonderful new grape of excellent quality and great productiveness.

“Campbell's Early vines are now being bought in larse lots by careful, wide awake vineyardists who want a grape which will hang on the vines, will not crack and which will keep and carl brimeted at advantageous times instead of having to be forcer on the niarket on some special day to avoid cracking and shelling. As a grod keeper and shipper it is believed to be unequalled by any other grape. Its early ripening is at same time as Moore's Early and at that time the quality of Campbell's Early is fully as good as Moore's Early. After that time the quality of Campbell's Early steadily improves for from two to six weeks, so its season is not only very early but is also medium and late."

In desert quality it is unrivaled by any of our present list of first early market grapes. It is, both as to cluster and berry, of large size, of a glossy black color, with a beautiful blue bloom, pulp sweet and juicy, free from foxiness, seeds small, few in number and part readily from the pulp.

They have been subjected to a temperature of 18 degrees below zero and have never been frozen in the least. Our stock is limited and will no doubt be sold early at prices quoted below.

CIINTON.-Late. Desirable for wine or preserving. Bunch and berry small; very healthy and hardy. Fruit should hang on the vine until after first frost, to be thoroughly ripe. Clinton is a profitable market variety.

\section{White Grapes}

NIAGARA.-This is the leading white grape throughout the country. Fruit is large and of fine quality. If you want a white grape we know of no other that equals Niagara. Occupies the same position among the white varieties as Concord among the black; most profitable market sort. Bunch and berries large, greenish white, changing to pale yellow when fully ripe; skin thin but tough. Every one should have a few white grapes.

\section{Red Grapes}

CATAWBA.- Tell known. Late; of best quality. Bunches large and loose; berries large, of a coppery red color, becoming purplish when well ripened.

As many of our customers have inquired for a red grape, we have bought a stock of Catawba and are able to quote them at prices given below. Our vines are fine, large, well rooted plants.

\begin{tabular}{|c|c|c|c|c|c|c|}
\hline & Prices of G & pe & ts. & & No. & \\
\hline cerd & Doz. & 100 & 1000 & $\begin{array}{l}\text { Doz. } \\
\$ 0.60\end{array}$ & $\begin{array}{l}100 \\
\$ 3.25\end{array}$ & $\begin{array}{c}1000 \\
\$ 28.50\end{array}$ \\
\hline $\begin{array}{l}\text { cord } \\
\text { rden }\end{array}$ & $\$ 0.50$ & $\begin{array}{r}\$ 2.23 \\
3.00\end{array}$ & $\begin{array}{r}\$ 20.00 \\
25.00\end{array}$ & $\begin{array}{r}\$ 0.00 \\
.70\end{array}$ & 3.95 & 33.00 \\
\hline oore's Eariy & $\begin{array}{r}.00 \\
60\end{array}$ & 3.00 & 25.0 & .75 & 4.00 & 35.00 \\
\hline ampbell's Early & 1.00 & 6.00 & 55.00 & 1.25 & 7.00 & 65.00 \\
\hline inton & .60 & 3.00 & 25.00 & .65 & 3.50 & 30.00 \\
\hline tawba & .6 & 3.00 & 2 & .65 & 3.50 & 30.00 \\
\hline agara & .60 & 3.00 & 25.00 & .65 & 3.50 & 30.00 \\
\hline
\end{tabular}

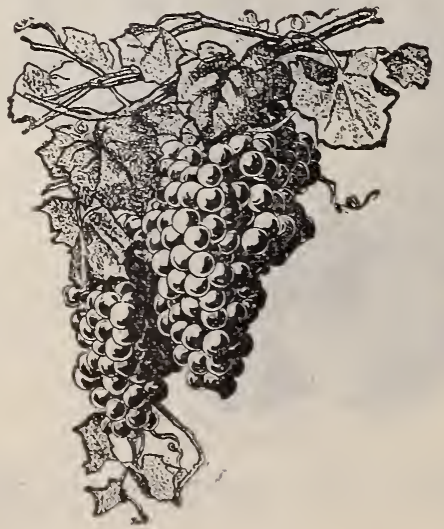




\section{Seed Potatoes}

We have grown quite a stock of several varieties of seed potatoes and will sell them at prices quoted below until stock is gone. Remember these prices are below those quoted in most all catalog:s. These potatoes are strictly No. 1 seed, guaranteed absolutely pure and unmixed. We will begin to ship early in March or as soon as weather permits us to ship with safety. Northern grown seeds are as much more desirable to plant than southern grown, as northern grown plants are more than those grown in the south. They are hardy and frse from disease and will yield a big crop.

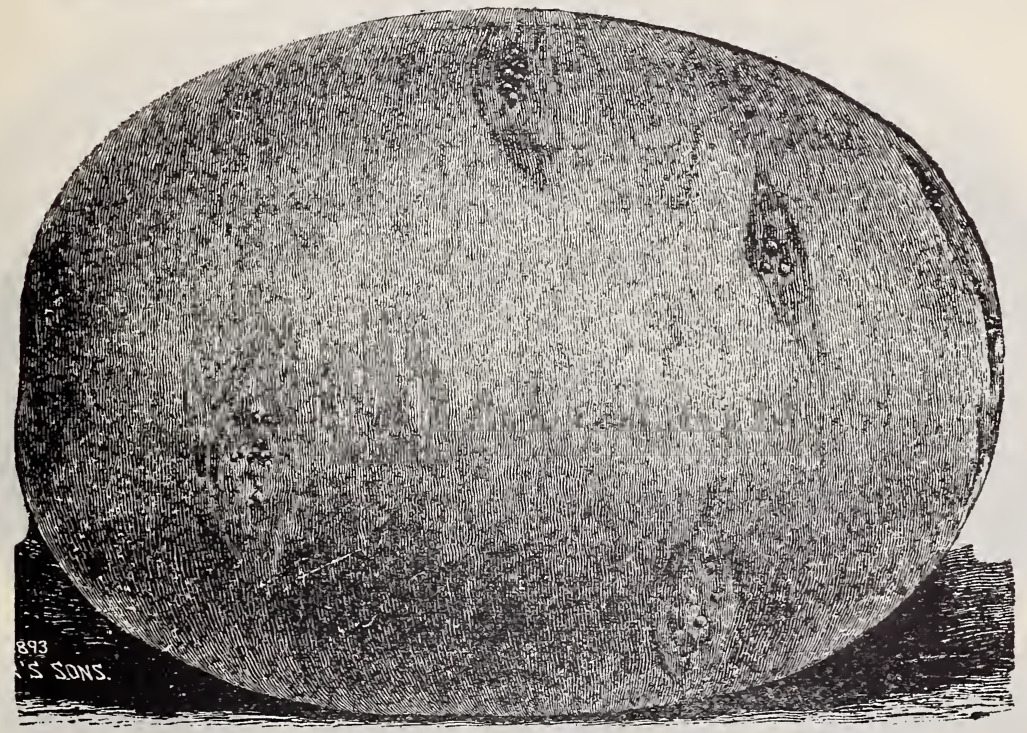

CARMEN NO. 3.

We will ship potatoes in sacks. Everything will be labeled and securely packed and delivered at the cars, without extra charge for sacks, ete.

Prices quoted are for No. $_{1}$ seed F. O. B. cars. We have but a small stock of all varieties combined and consequently. we will be sold out early. Remember, your order for potatoes must be received soon if you want your choice of varieties.

Peck, 15 Ibs.; Bushel, 60 ibs.; Earrel, 165ibs.

N. B.-If you prefer your potatoes shipped in boxes and barrels instead of sacks, add 10 cents per bushel or 25 cents per barrel to price herein quoted on each variety.

CARMEN NO. 3.-This we consider the best potato grown. We advise all to plant Carmen No. 3 for main crop either for home or market purposes. It makes great yields of fine, large, smooth tubers even under the most unfavorable circumstances and can be relied on to bring in money. It grows a very strong, upright top with dark colored stalks and purple blossoms and is little affected by drouth, blight or bugs. It is of the Rural family and keeps as well as Rural New Yorker and is fine for eating just as soon as dug in the fall. Very heavy yielder. Try Carmen No. 3 and make money. Price 35 cents per peck; \$1.10 per bushel; $\$ 3.00$ per barrel.

RURAI NEW YORKFR.-Very well and favorably known all over the country. Planted largely for main crop on account of its keeping qualities. A very late potato. Characterized by a long rather spindling vine with dark colored stalks, dark green leaves and purple blossoms; tubers nearly round, flattened 
with very smooth, pure white skin, uniform in size, numerous in the hill, very attractive. Better to eat in winter and spring than when first dug. One of the most profitable of market potatoes. A general favorite throughout the country on account of productiveness, uniform size, color and keeping qualities. If you buy a few barrels of Rural New Yorker for main crop you will never be sorry. Price 30 cents per peck; $\$ 1.00$ per bushel; $\$ 2.75$ per barrel.

WIITI FARIY OHIO.-A genuine Ohio with a white skin. Identical in every way with Early Ohio, except in color which is a fine white or nearly so. The great demand in every market now is for a white potato and even the good old Ohio, the standard for extra early, often has to suffer because of its skin. Here we have a genuine Early ohio with a quick, compact growth of that well known variety, and withal a white skin. Furthermore it is a better yielder than the old Ohio.

WHITE FARIY OHIO is, in our opinion, the best and most profitable early potato on the market to-day. They look nice, and are all right in every. way. You should try them. 50 cents per peck; $\$ 1.40$ per bushel; $\$ 3.75$ per barrel.

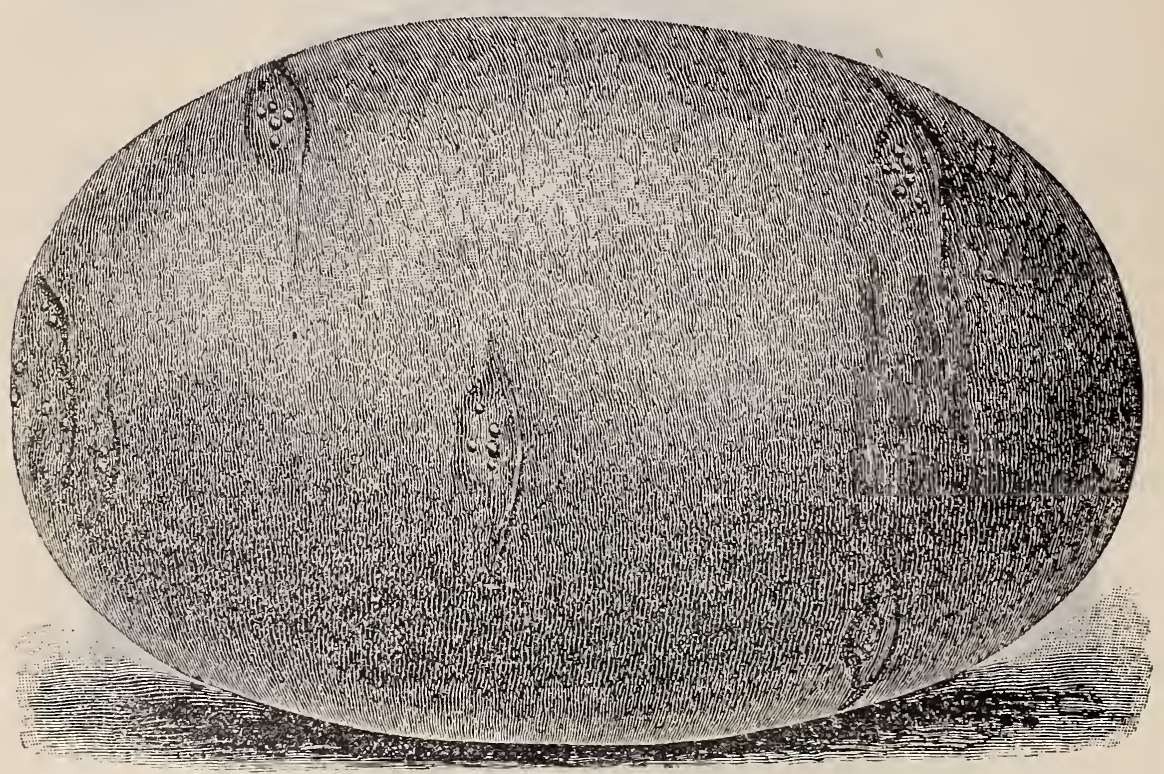

RURAL NEW YORKER.

EARLY ROSE.-Too well and favorably known all over the country to need description here. They have been raised profitably for many years and are grown extensively. They are red or rather a pink potato (like Hebron in color) and rather of oblong shape. We have but a few barrels of this variety, and we did not sort them. We will sell them just as they are, large and small. They make good seed as they are all ripe and in good shape. Price 30 cents per peck; $\$ 1.00$ per bushel; $\$ 2.75$ per barrel.

IRISA BELIF.-This new potato is a wonder. Yields more potatoes per acre than any other potato we have ever seen grown. They are of the Rural tere a litle more long shaped, and yield much me rhey are first class eating potatoes as soon as dug or late in the spring. A handsome and profitable potato. Colored about like Beauty of Hebron.

Irish Belle always sells readily upon the market as it is invariably a very large, even shaped, smooth, splendid looking potato.

We recommend it very highly as we know it will please you in every way. Price 35 cents per peck; $\$ 1.10$ per bushel; $\$ 3.00$ per barrel.

SIR WAITER RAIEIGH.-Cut below shows the shape of this fine new potato. Noted for its yield, size, smoothness and handsome appearance. It is a regular Rural New Yorker in type and sells for Rural in Chicago market; but it came out eight years later than that famous variety and has all that much 
advantage in strength and vigor. Good large size, hardly ever any small ones, nearly round in shape, but flattened, just what is most desired now; skin pure white, thin and transparent, eyes few and very shallow, potatoes never prongy and never scabby, almost blight proof, a sure yielder where others fail, in clay soils and all other soils. Sir Walter Raleigh is a good one and will not disappoint you. Price 40 cents per peck; $\$ 1.25$ per bushel; $\$ 3.25$ per barrel.

FARIY MAY.-They are clear white, round and flattened in shape (Jike Rural New Yorker), very uniform in size, and a heavy jielder, besides being one of the earliest if not the earliest potato in cultivaton to-day. We guarantee they will not disappoint you in any particular. Try them. We have no picture of Farly May, but will say that they'look very much like Carmen No. 3 . We did not sort but will sell just as they are. Good seed. Price 30 cents per peck; $\$ 1.00$ per bushel; $\$ 2.75$ per barrel.

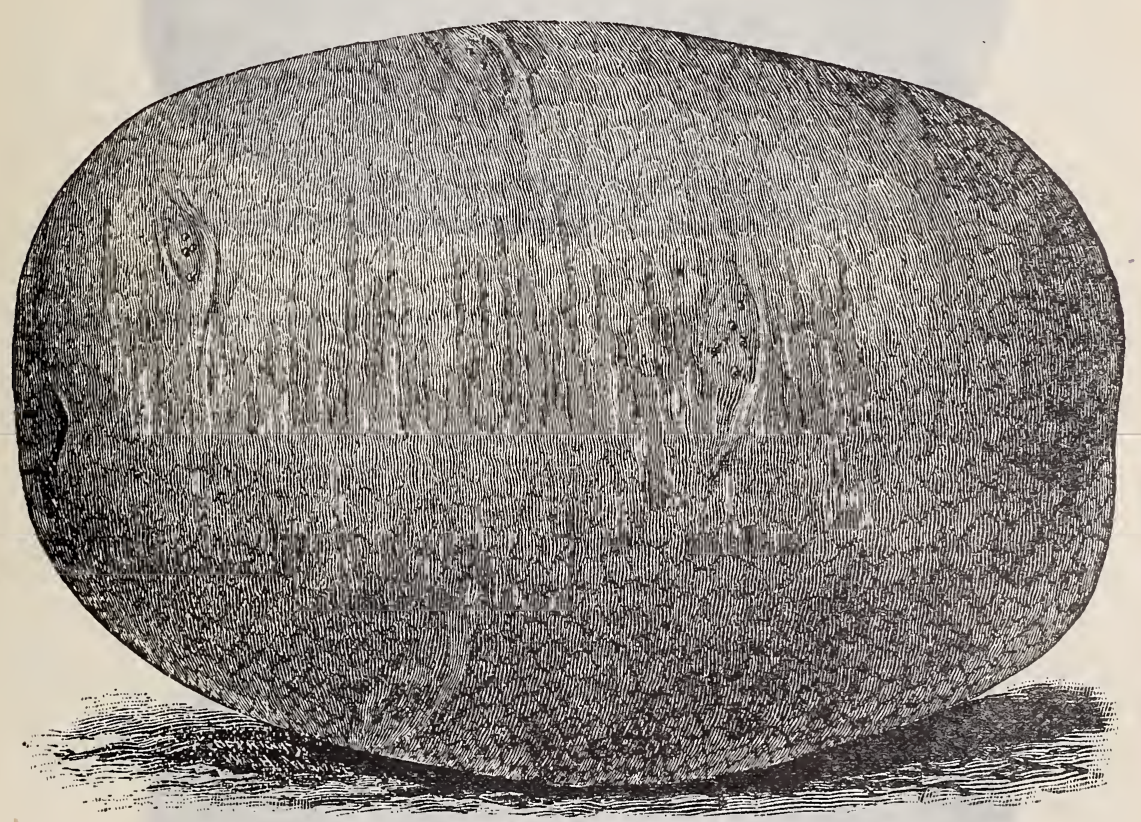

SIR WALTER RALEIGH POTATO.

FMPIRE STATF.-A widely known and largely planted late white potato. Long shaped, a good yielder, good keeper and always sells well on the market. Long shaped, of our most profitable potatoes. We have a good stock of Empire seed and it is fine. You will never regret having bought a few bushels of this grand white potato. Price reduced this year to 30 cents per peck; $\$ 1.00$ per bushel; $\$ 2.75$ per barrel.

TARIY MAINF.-A fine new early potato of exceptional value. We have only grown them two years but find them to be a fine looking, smooth potato yielding a good big crop. Early Maine has been one of our best paying potatoes this summer. Price 30 cents per peck; $\$ 1.00$ per bushel; $\$ 2.75$ per barrel.

ST. PATRICK.-A fine looking white potato. It is a long-shaped potato, but not so much so as Empire State. Season medium. Heavy yielder. Will stand druth well and is an all around profitable potato for home use or market. We recommend St. Patrick highly from our experience with it. Price on extra fine seed, 30 cents per peck; $\$ 1.00$ per bushel; $\$ 2.75$ per barrel.

BrAUTY OF HFBRON.-Too well known to need much description. Skin clear, but red. Nice, large, smooth, early potatoes. Raised in large quantities throughout the country. Beauty of Hebron is a good sure potato to plant for home use or market. Price 30 cents per peck; $\$ 1.00$ per bushel; $\$ 2.75$ per barrel. 


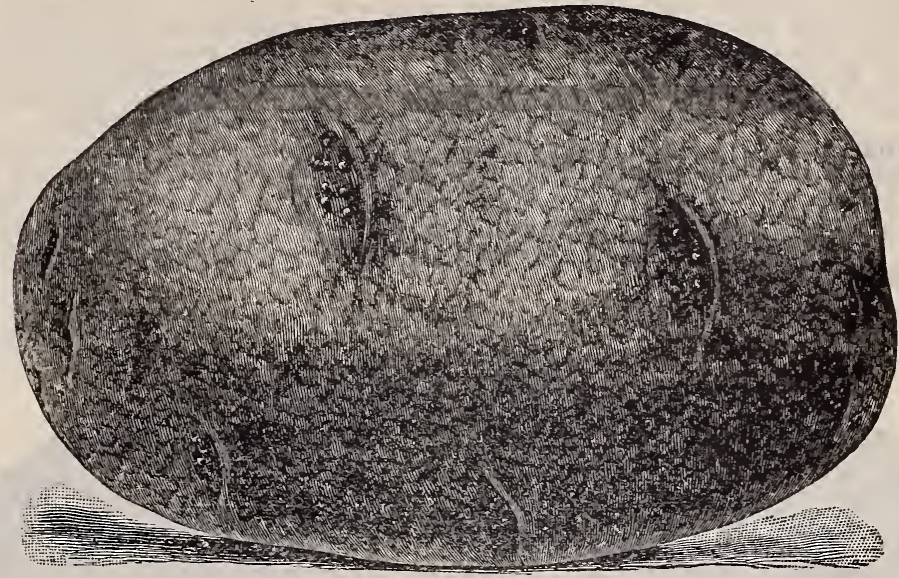

EARLY MAINE.

Remember the general shortage of potatoes this year and be prompt with your order.

If you want a quantity of seed Potatoes, do not fail to write us at once, stating just. what you want and we may be able to quote you a little better price.

Please remember that all potatoes are carefully put up in sacks, labeled and delivered to cars free of charge. All seed guaranteed to be pure and true to name and to reach you in good condition and give satisfaction.

Potato orders must come early or we may not be able to fill them.

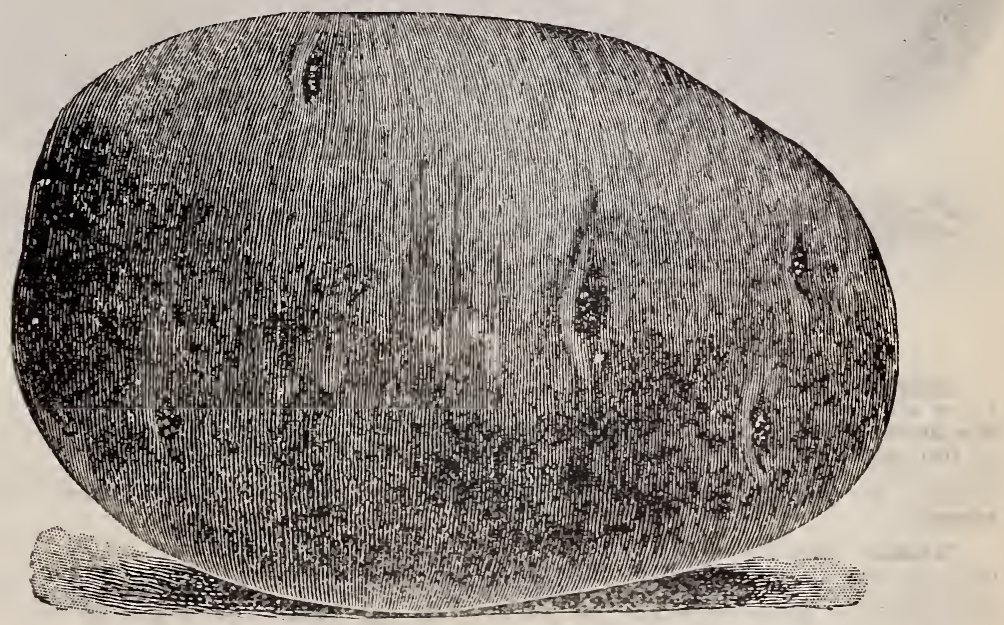

\section{BEAUTY OF HEBRON.}

"QUICK IUNCH."-Blight Proof.-This grand new Early Potato is so highly recommended in the east that we sent to Vermont and bought a small stock of it and now quote it to our customers in small quantities. It is an extra early potato that produces a heavy crop of large, even shaped, nice looking potatoes. They resemble Rural New Yorker in appearance but mature a heavy crop in six weeks from planting. They are white, smooth, round but flattened, and sell readi1y. Quick Lunch, 50c per peck; $\$ 1.75$ per bu. 


\section{Unsolicited Testimonials}

\section{(Ours Pay Him Best.)}

O. A. E. Baldwin, Bridgman, Mich.

Dear Sir:-Enclosed find order. I have come back with my order. I must say that the plants I have bought of you have paid me better than any I ever bought of anyone else.

$$
\text { Yours, }
$$

Hugh Wilson.

\section{(Have Always Been True-to-name.)}

O. A. E. Baldwin, Bridgman, Mich.

Blue Ash, Ohio, Jan. 30, 1906.

Dear Sir:-My former orders from you have always been nice plants and always true-to-name, so I send to you again. Yours,

W. F. Kennedy.

\section{(Iikes Our Packing.)}

O. A. E. Baldwin, Bridgman, Michigan.

Gravenmont, Ohio, April 20, 1905.

Dear Sir:-The 9,000 plants received in fine condition. Must say they are as good plants as ever I saw, and your style of packing is extra good.

I believe they would have arrived in Europe in good condition. Respectfully yours, H. CLAY MC KENZIE.

\section{(Knows They Are First-class and True-to-name.)}

O. A. E. Baldwin, Bridgman, Mich.

Dear Sir:- I can testify that the plants you send out are first-class and true--to-name which means a great deal to a person growing fruit. Last year I sent to Nek York for plants, but after this I will send to O. A. E. Baldwin, and get what $I$ want and what you represent it to be.

Yours, WM. HILL.

\section{(Ten Hundred Make 1000 in Ohio.)}

O. A. E. Baldwin, Bridgman, Mich.

Wauseon, Ohio, Apr. 24, 1906.

Dear Sir:-My plants came yesterday all right. Ten hundred makes a thousand in Ohio. Michigan laws must be different. There were 1100 plants in my thousand. The currants that you sent as premium are nice, also grape plants. Many thanks.

Respt., H. D. PALMER.

This is the Kind We Iike to Get.

-Read It-

O. A. E. Baldwin, Bridgman, Mich.

Zion City, Ill., Apr., 1906.

My $\$ 70.00$ order of plants rec'd and although I have bought plants from many places, yet I never saw such nice Raspberry plants in all my life. They are fine and cannot help but grow. Also the grapes, blackberry plants, current, gooseberry and strawberry plants, etc., etc., were first-class and rec'd in good order. Thanking you and assuring you of future trade, I am, Yours for business, C. H. SIMPSON.

\section{Fntirely Satisfactory for Ten Years. Likes Our Premium Paper.}

O. A. E. Baldwin, Bridgman, Michigan.

Fairfield, Iowa, Feb. 27, 1905.

Dear Sir:-I herewith send you a mail order for strawberry plants. I have bought plants from you for eight or ten years and they have always proven entirely satisfactory. "I have no kick coming." "Please renew my stubscription to The National Fruit Grower. I am very much pleased with the paper and think it is one of the best publications in the interest of fruit growers that I have ever read. 
(Price is Iress But Knows Plants are Better.)

O. A. E. Baldwin, Bridgman, Mich.

Monroe, Wisconsin, Mar. 13th, 1906.

Dear Sir:- In sending you my order again your catalogue prices are $\mathbf{5 0}$ cents less per thousand than other lists I have received this year but I feel sure that your plants are fully as good, as I have had them from you in previous years.

Yours very truly, IONE L. PHELPS.

\section{Satisfaction for Years.}

O. A. E. Baldwin, Bridgman, Michigan

Northville, Mich., April 18, 1905.

Dear Sir:- I enclose small order for plants. Please substitute if out of anything ordered. I have dealt with you for a number of years and am very much pleased with your plants.

Very truly.

DEAN F. GRISWOLD.

Satisfied for Six Years.

O. A. E. Baldwin, Bridgman, Michigan.

Wemple, N. Y., July 16, 1906.

Dear Sir:- I have sent you orders every year for six or seven years, and the plants have always been satisfactory in every way. Enclosed find my order.

Very truly yours,

J. E. LEEDINGS.

Just Received as We go to Printers.

Locust Point, Ind., Dec. 17, 1906.

O. A. E. Baldwin, Bridgman, Michigan.

Dear Sir:-I have been well pleased with the plants I received from you. They were the best I ever saw. Thanking you very much for your honesty, I am,

Respectfully.

ADOLPH HENRIAT'T

\section{We Are Making a Reputation for Ourselves With Our Seed Potatoes.}

(Well Pleased.)

O. A. E. Baldwin, Bridgman, Mich.

Downers Grove, Apr. 26, '06. Dear Sir:-Potatoes have been received by freight and we are well pleased with them.

Sincerely yours, C. E. MOOAR.

\section{(Our Potatoes Yielded Well.)}

O. A. E. Baldwin, Bridgman, Mich.

Monroe City, Feb. 20, '06.

Dear Sir:-Potatoes received last year were excellent and have yielded well. I have been buying of you for twelve years, and could not wish for better plants and potatoes.

\section{J. A. BIXLER.}

\section{(Liked Potatoes,-Ordered Again.)}

O. A. E. Baldwin, Bridgman, Mich.

Springfield, Ohio, Mar. 23, '06. Dear Sir:-Please forward potatoes. I bought my potatoes of you two years ago, and they were fine.

Yours resp., WM. J. CRIST. 


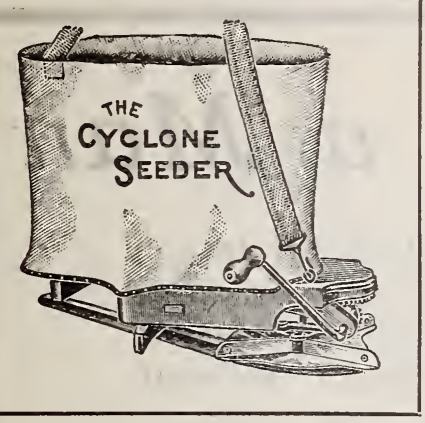

\section{THE "CYCLONE"}

the best and most desirable HAND BROADCAST SEED SOWEB made. This sower has stood every test of nearly forty years exacting service. The workmanship and material used in its construction are of the best available.

The CYCLONE differs materially and very advantageously from all other Sowers in having a slope feed board and oblong hopper which terminates in a metal edge on which edge oscillates a steel feed plate which does not allow the seed to become clogged, but makes a positive FORCE FEED and insures a uniform flow and even distribution of all farm seeds. The feed gauge can be adjusted closely for any kind of seed and opened or closed instantly and automatically without disturbing the adjustment. Full directions accompany each machine. Every one warranted. Price $\$ 1.50$ each.

THE CHICAGO (BOW) SEEDER is run by a backward and forward movement of a steel bow through a swivel guide. Otherwise it is like the Cyclone in construction. Price $\$ 1.40$ each.

THE LITTLE WONDER SOWER is practically and mechanically built, neatly finished and has the same automatic feed shutoff and agitating device as the Cyclone and Chicago machines. Anyone seeking a moderate price machine will find excellent value in the Little Wonder. Price $\$ 1.25$ each.

These goods are sold by the trade generally, and if you cannot secure them from your dealer we will send you, upon receipt of price, any of the above machines BY PREPAID EXPRESS. Do not accept a substitute.

\section{CYCLONE SEEDER CO., MFGRS. URBANA, INDIANA, U.S.A.}

NOTICE: Having used the Cyclone Seeder on my farms, I can unhesitatingly recommend same to my patrons as a strictly accurate and high grade machine. With an order for nursery stock selected from this catalogue we will include any one of the above Seeders for 25e less than price named, express not prepaid. WE GUARANTEE SATISFACTION.

$$
\text { O. A. E. Baldwin. }
$$




\section{We Want a Man}

Young or old, in every locality, to get around and see the Fruit Growers; people who want to know the best way of growing fruit of all kinds, as well as how to market it, and make a success of this very important indus= try. If you show the paper you will get the subscriptions. We will make the terms attractive, and furnish you with sample copies and blanks.

\section{The National Fruit Grower}

is a paper of National Reputation, is eleven years old and has first place in its field. We have in our files a letter that came after our December, 1906, issue, saying it was the best paper the writer had ever seen, had the most reading matter of value to the people growing fruit, of any publication ever issued.

Write us if you will try it and we will fix you up with full instructions and materials for making good money on easy sales.

You can easily make from three to five dollars a day for the work of a few hours. Will you be one to try it? You had better, it is a good chance to make easy money. Address,

The National Fruit Grower, St. Joseph, Mich. 

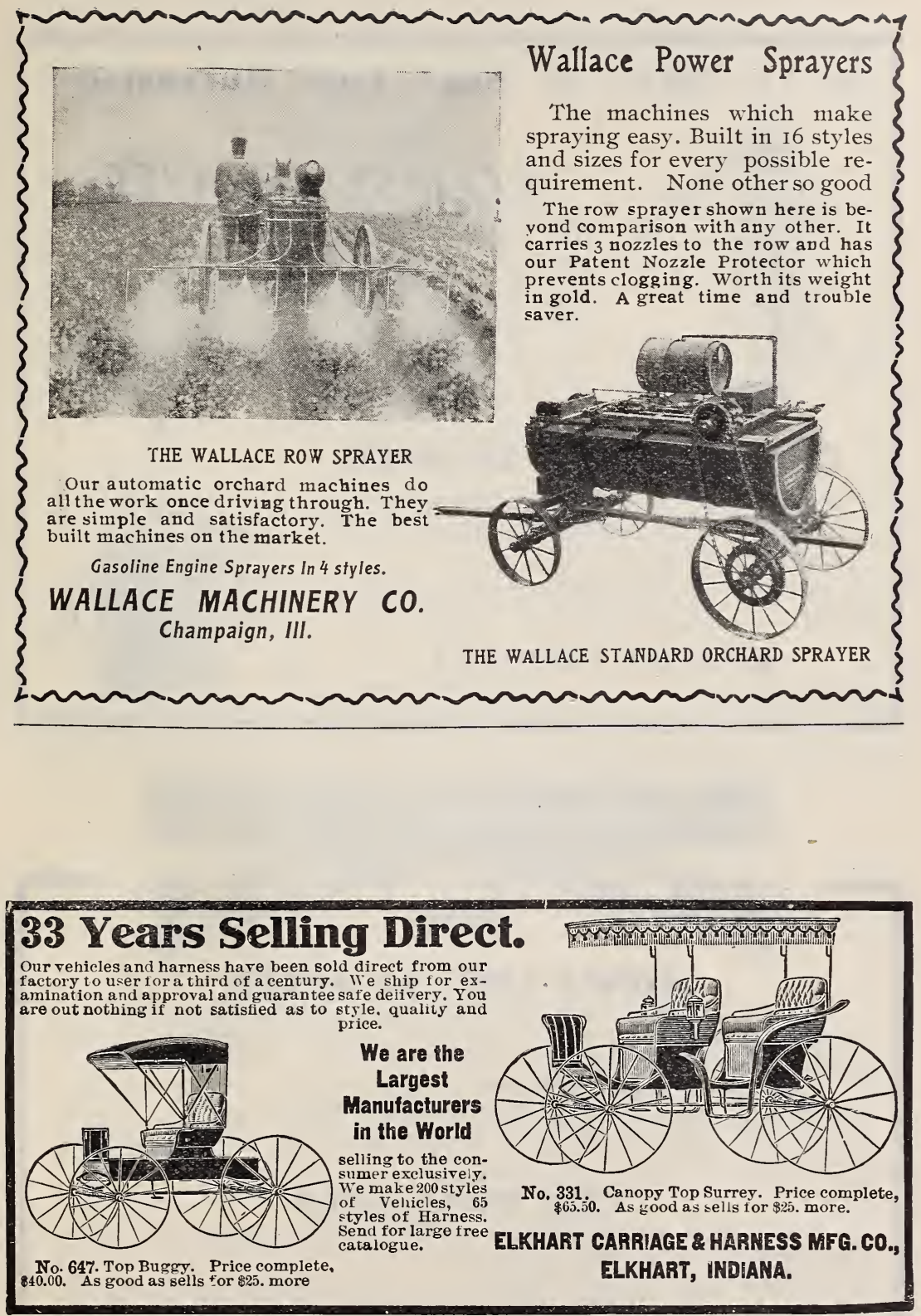


\section{As Ye Spray, So Shall Your Harvest Be!}

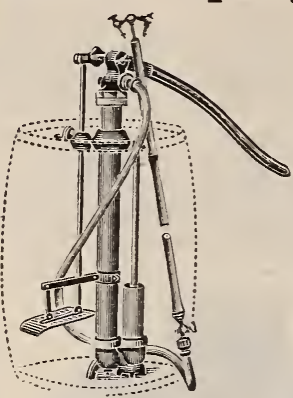

And if you use the

\section{ECLIPSE SPRAYER}

YOU WILL SAVE DOLLARS, because it throws a perfect spray and covers every particle of the tree, bush or vine. It puts the spraying material where it will do the most good, insuring greatest economy.

We invented the Eclipse Spray Pump after experimenting for years in our own orchards, with the common sprayers, and thousands of users testify that it is the best spray pump made.

\section{OUR KNAPSACK SPRAYER}

Is just the thing for the family fruit garden, because it will keep vour strawberries, grapes, fruit trees, and all brush fruits free from insects and fungi. The Knapsack is made from the same material as our Eclipse pump.

All three of these machines and many other aids to successful horticulture are fully illustrated in our 40-page cata logue. It is brimful of valuable information for the gardener and fruitman. It is free to you. Send For if Today.

\section{Elm Street - * Benton Harbor, Mich.}
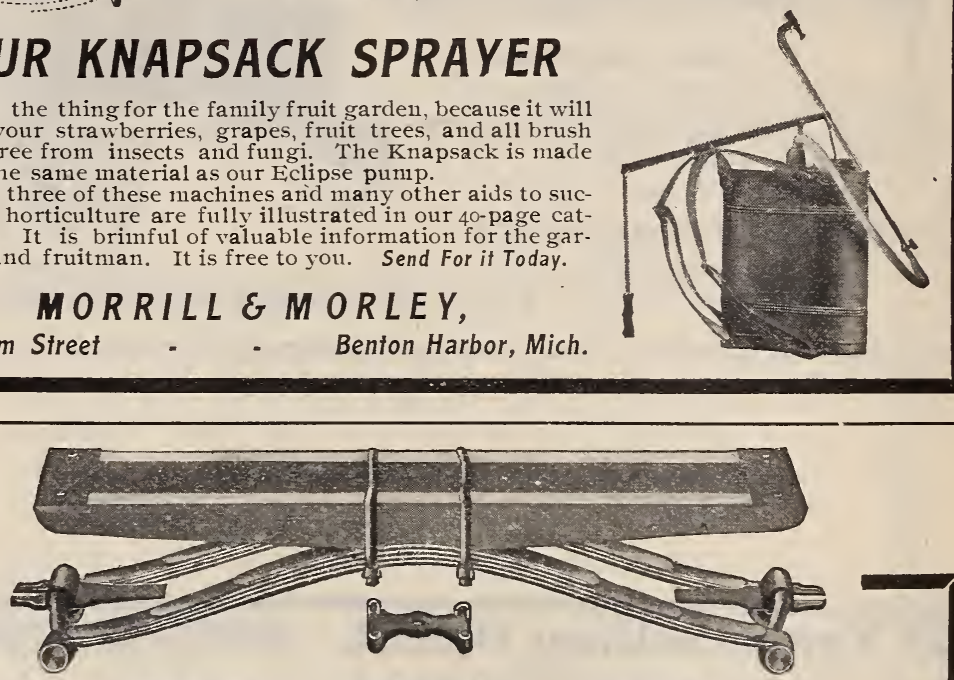

\section{MONEY LOST IN JOLTS}

Can you estimate how much your wagon and loads of stock, fruit and produce are injured by lack of springs? It may not seem much when given only a passing thought, but those who have tried Bolster springs know that it is considerable.

FARVIY BOISTIR SPRINGS are made of the finest spring steel tempered to the point of perfection, rigidly tested and tried. They fit any Farm Wagon. We unreservedly guarantee these springs for all time. If from any defect of material or workmanship a Harvey spring does not give satisfaction at any time-one year or ten years-we will make it good without a word of argument.

\section{FREE TRIAL OFFER}

Every dealer is authorized to let Harvey Bolster Springs out on 30 Days Free Trial. If they fail to give perfect satisfaction, return them and the trial will not cost one cent.

We sell only through dealers-it's more economical and you see what you're getting before buying. If you're dealer does not sell Harvey springs, ask him to write us mentioning your name. We'll send him prices and you will get a Useful Souvenlr with full particulars about Harvey Bolster Springs. It is a pleasure to ride in a farm wagon fitted with our springs.

HARVEY SPRING CO., - - 98 Carver Ave., Racine, Wis. 
ORDER SHEET

\section{O. A. E. BALDWIN, Bridgman, Mich.}

Name

\section{Post Office}

County

State

Express Office

Exp. Co.

Freight Sta.
Amount Enclosed

P. O. Order $\$$

Ex. Order \$

Draft $\$$

Cash

$\$$

Total \$

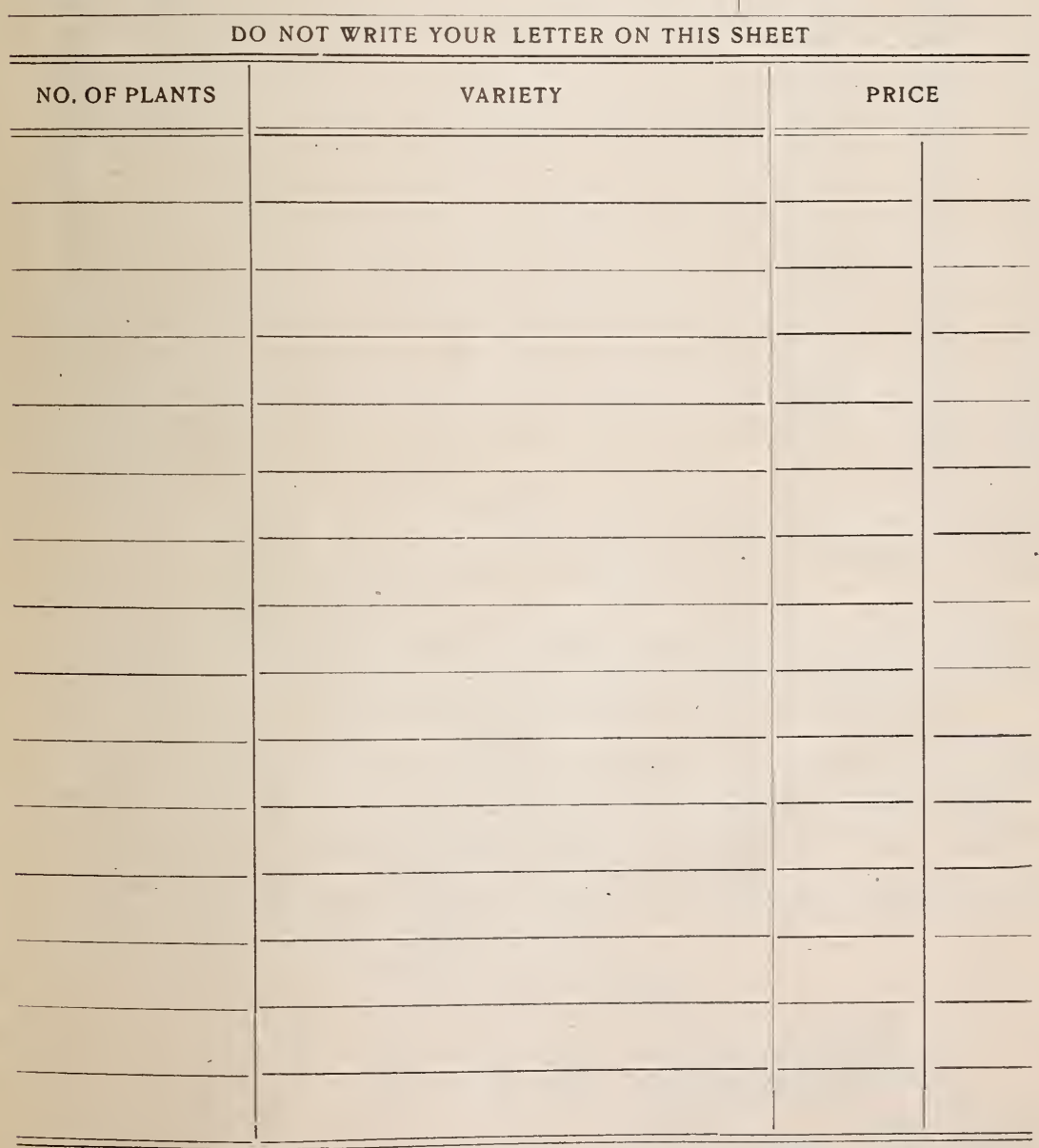

SPECIAI With every order of Three Dollars and over, at catalogue SPECIAL OFFER price we will give free a year's subscription to The National Fruit Grower, the largest horticultural and fruit trade journal west of New York. Published monthly. If you accept this offer please write "O. $\mathrm{K}$." in the square. Regular subscription price, $\mathbf{5 0}$ cents. 
If you are sure some of your neighbors would appreciate our Catalog, will you please write their names and addresses below? 


\section{Prices on Strawberry Plants for 1907.}

August Inther, (S) $\ldots \ldots \ldots \ldots \ldots \ldots \ldots \ldots \ldots \ldots \ldots \ldots \ldots . \$ 0.25 \quad \$ 0.50 \quad \$ 2.50$

Aroma, (S) $\ldots \ldots \ldots \ldots \ldots \ldots \ldots \ldots \ldots \ldots \ldots \ldots \ldots \ldots \ldots \ldots .25 \quad \mathbf{. 5 0} \quad \mathbf{3 . 0 0}$

Brandywine, (S) $\ldots \ldots \ldots \ldots \ldots \ldots \ldots \ldots \ldots \ldots \ldots \ldots \ldots \ldots \ldots .25 \quad 3.00$

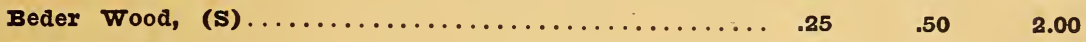

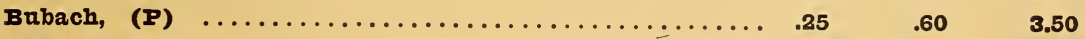

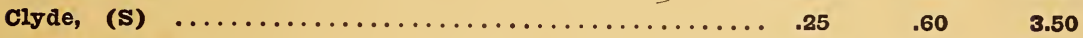

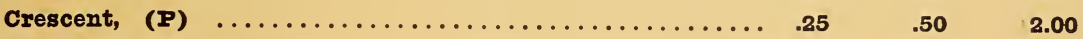

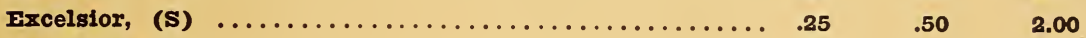

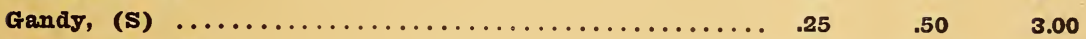

Glen Mary, (S) $\ldots \ldots \ldots \ldots \ldots \ldots \ldots \ldots \ldots \ldots \ldots \ldots \ldots \ldots \ldots .25 \quad 3.60$

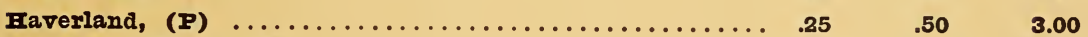

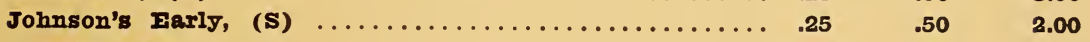

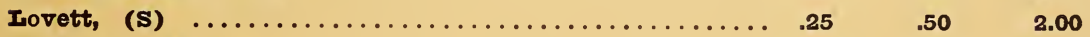

Marshall, (s) $\ldots \ldots \ldots \ldots \ldots \ldots \ldots \ldots \ldots \ldots \ldots \ldots \ldots \ldots \ldots \ldots 25 \quad \mathbf{. 7 5} \quad 4.00$

Michel' Farly, (S) $\ldots \ldots \ldots \ldots \ldots \ldots \ldots \ldots \ldots \ldots \ldots \ldots \ldots \ldots .25 \quad 1.75$

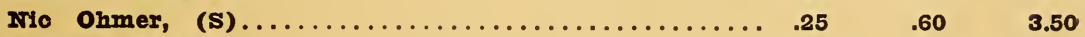

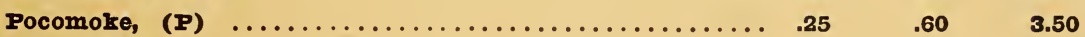

Splendid, (S) $\ldots \ldots \ldots \ldots \ldots \ldots \ldots \ldots \ldots \ldots \ldots \ldots \ldots \ldots \ldots .25 \quad .25$

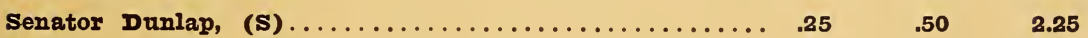

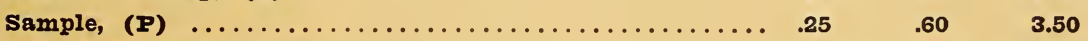

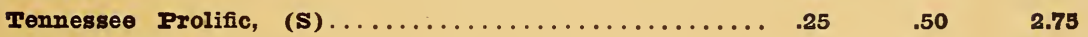

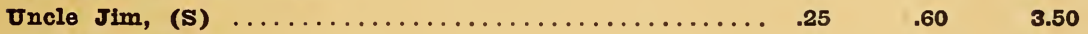

Warfield, (P) $\ldots \ldots \ldots \ldots \ldots \ldots \ldots \ldots \ldots \ldots \ldots \ldots \ldots \ldots \ldots .25 \quad \mathbf{. 5 0} \quad 2.00$

wm. Belt, (S) $\ldots \ldots \ldots \ldots \ldots \ldots \ldots \ldots \ldots \ldots \ldots \ldots \ldots \ldots \ldots .25 \quad 3.25$

Varieties marked (P) are "Pistillate and should have about every fourth row set to some staminate variety as a fertilizer. Those marked (S) are "Staminate" and good fertilizers

Six of variety at dozen, 25 at 100 and 250 at 1,000 rates. At dozen rates we pay postage. At 100 rates to go by mail, add 25 cents to each 100; at 100 and 1,000 rates to go by express or freight, charges to be paid by purchaser.

Small fruit plants are scarce and the demand will exceed the supply in the spring of 1907. We advise all to place thelr orders early and be sure of getting what you want, besides taking advantage of our discount for early orders.

If you want a quantity of plants, write us AT ONCE for special quotatlons.

May we not hear from $Y O U$ before our rush comes?

AWAITING FOUR FAVORS WHICE WIII RECFIVE CAREFUI ATD PROMPT PFRSONAT ATTEITION, I AN,

VIRY TRUIY YOURS,

\section{A. E. BALDWIN,}

\section{Bridgman, Michigan.}

Iong Distance Telephone, call Bridgman. 
JAMTS M. BAII, Pres.

M. W. STOCK, Vice-Pres.

A. N. BFFCF, Cash.

THOS. S. CIAREF, Ass't Cash.

\section{-The- \\ Commercial National Bank,} ST. JOSEPH, MICHIGAN.

CAPITAL $\$ 50,000.00$

SURPLUS AND UNDIVIDED PROFIT \$15,000,

Money to Loan at All Times at the Lowest Rates.

The patronage of FARMERS and FRUIT GROWERS is respectfully solicited.

The Rhodes Double Cut Pruning Shears PATINTID

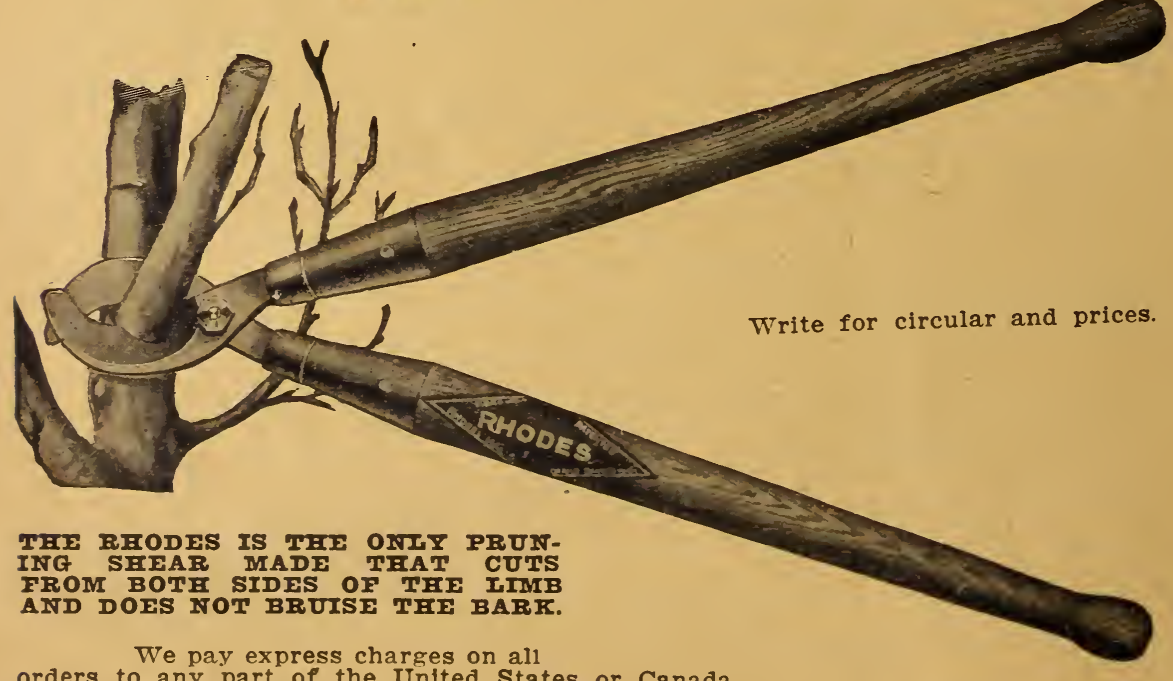
orders to any part of the United States or Canada. RHODES MANUFACTURING CO. 